\title{
Subsidies or loans? Evaluating the impact of R\&D support programmes
}

\author{
Elena Huergo \\ GRIPICO-Universidad Complutense de Madrid* \\ Lourdes Moreno \\ GRIPICO-Universidad Complutense de Madrid*
}

April 2017

\begin{abstract}
$\underline{\text { Abstract }}$
The objective of this study is to compare the effect of different types of public direct support for R\&D projects on firms' technological capabilities. We distinguish between low-interest loans and national and European subsidies. Using data on 4,407 Spanish firms during the period 2002-2005, we estimate a multivariate probit to analyse the determinants of firms' participation in public R\&D programmes and, later, the impact of this participation on firms' R\&D activities using two different procedures. Regardless of the methodology employed for the analysis, the results suggest that being awarded any type of direct aid clearly increases the probability of conducting R\&D activities. In terms of being supported through a unique instrument, the greatest effect corresponds to the case of European grants, where the impact is more than three times larger than the one of loans. As for R\&D intensity, the hypothesis of full crowding-out of private $R \& D$ is rejected for all types of support. In addition, we find that the impacts of subsidies and loans reinforce each other when they are jointly awarded to SMEs. However, for large firms we cannot rule out the existence of crowding-out effect between subsidies and loans.
\end{abstract}

Keywords: Soft loans, R\&D subsidies, impact assessment

J.E.L. Classification: H81, L2, O3, L52

This research has been partially funded by the Seventh Framework Programme (Ref.: 290597) and by two research grants from the Spanish Ministry of Science and Innovation (Ref.: ECO2010-19847, ECO2014-52051-R). The authors thank the CDTI for the transfer of the data to carry out this research. The authors benefited from presentations at XVII Applied Economics Meeting (Las Palmas de Gran Canarias, 2014), 41th EARIE Annual Conference (Milan, 2014), XXIX Jornadas de Economía Industrial, (Barcelona, 2014), the seminar at the Department of Economy (Universitat Rovira i Virgili, Reus, 2014), the Economic \& Finance Seminar Series (Universita Cattolica del Sacro Cuore, Milano, 2015) and especially from suggestions by Miguel Manjón, Oscar Martínez, Pierre Mohnen, Gabriele Pellegrino, and three anonymous reviewers.

* GRIPICO (Group for Research in Productivity, Innovation and Competition). Dpto. Fundamentos del Análisis Económico I. Facultad de CC. Económicas y Empresariales. Universidad Complutense de Madrid. Campus de Somosaguas. 28223 Madrid. España. e-mail: ehuergoo@ucm.es; $\underline{\text { lmorenom@ucm.es. }}$ 


\section{INTRODUCTION}

In the tradition of the economic literature, public support of research, development and innovation (R\&D\&I) activities is mainly justified by the existence of market failures (Hall, 2002; Hall and Lerner, 2010). The 'public good' nature of knowledge prevents full appropriation, which pushes private R\&D\&I investment below the socially optimal level. In addition, innovating companies may suffer from a financing deficit due to the presence of information asymmetry and moral hazard. Private financers may be reluctant to lend when the investment is concentrated essentially on intangible assets. This situation results in a higher cost of financing with respect to ordinary investment and a lower level of private external funding of R\&D\&I activities. These market failures would be greater for small firms and technologyintensive start-ups (Hall, 2002). Through aid programs, public agencies implicitly certify these companies, reducing the information asymmetries and helping these firms to face financial difficulties.

Public intervention could also have negative effects. Public support would displace private R\&D spending if awarded firms reduce their own R\&D investment beyond the level that would have been performed without the aid (Zúñiga-Vicente et al., 2014). Innovation policy could be captured by permanent R\&D performers, and politicians or interests groups may seek to allocate subsidies to benefit themselves (Lerner, 2002), selecting firms based on their likely success, regardless of a low marginal contribution of public aid.

Taking this into account, there is a great deal of empirical evidence on the impact of public aid on private R\&D (see David et al., 2000, Zúñiga-Vicente et al., 2014, and Becker, 2015, for a review). The variety of empirical methodologies used for this assessment is wide, including specific techniques to control for potential endogeneity of public support, nonlinearities and firm heterogeneity (Wallsten, 2000; Busom, 2000; Lach, 2002; Duguet, 2004; González et al., 2005; González and Pazó, 2008; Czarnitzki and Licht, 2006; OECD, 2006; Clausen, 2008; Takalo et al., 2013). Many of these studies infer that direct support generates larger additionality at the extensive margin (share of R\&D performers) than at the intensive margin (R\&D intensity of actual performers). However, most papers consider only one programme in their analyses and this fact makes it difficult to accurately compare the impacts among funding systems, which can differ in their objectives, the national or supranational character of the supporting entity and the funding scheme (Blanes and Busom, 2004). In this sense, it seems reasonable that their evaluation also provides different results. 
Three exceptions are the papers by García and Mohnen (2010), Czarnitzki and Lopes- Bento (2014) and Liu and Rammer (2016). In all cases, the empirical analysis is based on microdata from the Community Innovation Survey (CIS). The first one compares the impact of public support from the central government and the European Union (EU) on the innovation of Austrian firms, using the third wave of the CIS, which covers the years 1998-2000. To measure the effectiveness of these programmes, the authors propose a structural model of the endogeneity of innovation and of public support for it. The estimation of this model by the method of asymptotic least squares suggests that receiving central government support increases the intensity of R\&D by 2.3 percentage points and yields a 2.5 percentage point increase in the share of sales of new to firm products. However, EU support is never significant once national support is taken into account.

The study by Czarnitzki and Lopes-Bento (2014) also offers a comparison of the impact of national and European funding on innovation intensity and performance. The empirical analysis is based on the German part of the CIS for seven waves but, as the data can only be used as pooled cross-sections, to face the endogeneity problem, they apply a variant of a nonparametric matching estimator. In terms of innovation input, their results provide evidence that getting funding from both sources displays the highest impact, while EU subsidies have higher effects when the firm receives funding from only one source. As for innovation performance, funding from both sources again yields higher sales of market novelties and patent applications, but in this case the impact of national funding is superior when only one type of grant is obtained.

Liu and Rammer (2016) analyse the effectiveness of regional, national and European funding programmes implemented in Germany on both product and process innovations and on export performance of small and medium-sized enterprises (SMEs). Using also a panel dataset from the German part of the CIS from 2001 to 2014, they find that public financial support contributes to higher innovation outputs, which in turn translate into higher export success in later years. But this relation only holds for certain sources of public funding and certain types of innovation output.

To contribute to this literature, in this paper we investigate the role of two specific dimensions of supporting schemes: the national or supranational character of the financing agency, which is usually associated with the national or international character of the R\&D project, and the magnitude of reimbursement implied in design of the public support. In particular, to our 
knowledge, no previous empirical research exists comparing the effects of public subsidies and loans on private $R \& D$. With this objective, we analyse the effect of participation within three different public funding programmes on the technological performance of Spanish firms. Specifically, we consider public programmes based on low-interest loans versus national and European innovation subsidies and we distinguish between their effects on extensive and intensive margins. We also contribute to the literature by studying the existence of possible differences in the treatment effects between small and medium-sized enterprises (SMEs) and large firms.

For this purpose, we integrate two data sets. The first one is provided by the Centre for the Development for Industrial Technology (CDTI). This public organism grants financial help of its own to companies and facilitates access to third-party funds for the execution of both national and international research and development projects. During the period 2002 to 2005, the CDTI awarded zero-interest loans that could reach $60 \%$ of the total budget of the R\&D project, with a period of repayment of up to 10 years.

The second database is provided by the National Institute of Statistics (INE) and corresponds to a sample of innovative firms from the Spanish Technological Innovation Survey (the Spanish version of the CIS). From this database we obtain the information about public subsidies for innovation activities from the different levels of government. Overall, we compile a homogeneous sample that consists of an unbalanced panel of 13,546 observations and 4,407 firms for the period 2002 to 2005. Specifically, 2,185 of them have received some type of public support for their R\&D projects during the period.

The factors taken into account to apply for a low-interest loan from the CDTI or for a national or European subsidy can differ. However, some of them may be the same as those that affect the firm's R\&D decision. This fact can generate a bias in the impact of these funding instruments on the innovative performance of firms if the CDTI or other public domestic and foreign organisms award firms with a better technological profile.

To deal with this selection problem, in this paper we follow two different methodologies. Firstly, we use a Heckman's treatment effect model. The first stage in this model consists of the estimation of a multivariate probit model to study the determinants of each of the three schemes of public support. In the second stage, we analyse how this participation affects the R\&D intensity of the firms. Secondly, we complement the study by performing an economet- 
ric matching technique. This procedure allows us to test whether there is substitutability or complementarity among the different public funding policies.

Our results confirm that, regardless of the methodology employed for the analysis, the three instruments are effective to stimulate the extensive margin. As for the intensive margin, the hypothesis of full crowding-out of private $R \& D$ is also rejected for all types of support. In addition, the impacts of subsidies and loans reinforce each other when they are jointly awarded to SMEs. However, for large firms we cannot reject the hypothesis of crowding-out effect between subsidies and CDTI loans.

The rest of the paper is organised as follows. In Section 2, we highlight how some characteristics of support programmes can justify their different impact on firms' R\&D activities. In section 3, we summarize the main features of innovation policy in Spain regarding financial support. In Section 4, we describe the empirical model and the data. Section 5 shows the estimates and discusses the results. Finally, we present key conclusions in Section 6.

\section{THE LINK BETWEEN INNOVATION IMPACT AND PROGRAMME FEATURES}

Assessing the impact of public support of firms' R\&D projects on R\&D\&I activities requires a clear understanding of the design of public programmes. Although the general design of an R\&D programme is likely to have an impact on innovation, it is difficult to clearly associate certain design features of R\&D programmes with (not directly intended) innovation (European Commission, 2009).

Among innovation policy instruments, the type of public intervention more devoted to the reduction of the gap between the social and the private return of $R \& D$ investments is financial support, which can be direct, through subsidies or low-interest loans, or indirect, mainly through R\&D tax credits.

The three public programmes analysed in this paper are different types of direct financial support. In all cases, to obtain the aid the firm must submit an application that is rated by the agency mainly in terms of its R\&D excellence. However, supporting schemes differ in two specific dimensions: the national versus supranational level of the programme and the reimbursable character of the aid. As for the first aspect, why should we expect a different impact 
of R\&D subsidies depending on the government level of the supporting organism? There are at least three reasons.

First of all, the design of $R \& D$ programmes can differ between public agencies of different levels of governance, especially when they have specific objectives. Although the main justification for public intervention is the correction of market failures, the aims of public support can also consist of stimulating specific groups such as R\&D champions (picking-the-winners strategy), SMEs with major financial constraints to undertake R\&D projects, or companies in sectors with large knowledge externalities. In addition, in the case of national agencies, the objective could be the technological updating of firms in traditional or declining sectors (see Blanes and Busom, 2004), where by the agencies try to increase the probability of survival and avoid employment losses. And depending on the final objective, selected projects can be more or less market-oriented or focused on core technologies of participants. For instance, the Framework Programme (FP) of the European Union is characterised by the participation of universities and research institutes in consortia and the relevance of pre-competitive research, while the Eureka Programme is more market-oriented (Benfratello and Sembenelli (2002).

Alternatively, as Busom and Fernández-Ribas (2007) point out, programmes implemented by different jurisdictions could be complementary if the agencies coordinate efficiently to take into account the nature and extent of spillovers and other relevant market failures. In fact, most supra-national policies are justified by the existence of cross-border spillovers and economies of scale. In this line, Busom and Fernández-Ribas (2007) test whether the Spanish government and the European Commission have different selection criteria for awarding R\&D subsidies to firms. They conclude that the determinants of firm participation in each programme are different, suggesting that these programmes do not systematically overlap expost, as intended ex-ante by policy makers.

A second argument is related to the different costs of application in each programme (Czarnitzki and Lopes-Bento, 2014). These application costs are mainly related to bureaucratic and administrative requirements that are enlarged when the procedure of granting implies a negotiation phase. Firms usually perceive this negotiation phase as resource-consuming, delaying the timing of the R\&D project (Barajas and Huergo, 2010).

In addition, application costs increase with coordination costs in the case of programmes that imply the existence of self-organised consortia, as often happens in supra-national R\&D pro- 
grammes. The organisation of the network of partners, the formulation of the proposal and the daily monitoring of the project usually entail higher overhead costs in time and human resources than in the case of individual R\&D projects.

And a third reason for having different impacts among programmes has to do with the size of expected knowledge spillovers. These spillovers refer both to the company's ability to capture information flows from the public pool of knowledge (incoming spillovers) and to the ability to control information flows out of the firm (outgoing spillovers) to appropriate the returns from innovation.

The measurement of these spillovers is especially complex in cooperative R\&D agreements. In fact, as Cassiman and Veugelers (2002) find out, there is a significant relation between external information flows and the decision to cooperate in $\mathrm{R} \& \mathrm{D}$, and the level of knowledge inflows and outflows is not exogenous to the firm. This element is especially important for our analysis, as projects financed through supra-national programmes usually correspond to Research Joint Ventures (RJVs) that involve partners from different countries. In this case, the technological capabilities of subsidised firms can be affected not only by public aid but also by spillovers of cooperation among partners. However, most papers that study the impact of public programmes that support RJVs consider R\&D collaboration and R\&D public support to be an integrated treatment (Benfratello and Sembenelli, 2002; Bayona-Sáez and GarcíaMarco, 2010; Kaiser and Kuhn, 2012; Barajas et al., 2016). An exception is the paper by Czarnitzki et al. (2007), who interpret RJVs and subsidies as heterogeneous treatments for a sample of German and Finnish firms. Although they find that the combination of both treatments has a positive impact on the firm's R\&D expenditures or the number of patents, when cooperation and public support are separately analysed, subsidies for individual research do not significantly affect R\&D or patenting by German firms.

The reimbursable character of public support is a second dimension that could affect our analysis when comparing the effect of subsidies and loans. Firms tend to have fewer incentives to apply for loans than for grants in case of high-risky projects, as they would have problems to pay the principal back in the case of failure. However, as perceived by programme managers, the existence of private co-funding is highly relevant for innovation impact (European Commission, 2009). In addition, although preferential (below market) or low-interest loans in fact imply a hidden subsidy in terms of interest savings, they are fully compatible with fiscal incentives, while subsidies in many cases imply that firms cannot benefit from tax 
cuts that are related to R\&D investments. Furthermore, the percentage of the firm's budget that is allocated to the project is higher than usual, and the signalling effect of the agency awarding in terms of quality certification of the project is stronger, making it easier to obtain private financing outside the company (Huergo and Trenado, 2010). Subsidized loans also self-enforce more discipline on the recipients, as the monitoring of the project development by the agency is also higher. For these last reasons, low-interest loans should be expected to generate higher efficiency than the equivalent subsidy in terms of the generation of product or process innovations.

\section{INNOVATION POLICY IN SPAIN}

In general, the design of innovation policy tends to balance the fulfilment of the objectives of public administrations and the costs of political action. As a consequence, there is a great variability of public instruments among countries. Regarding R\&D financial support, countries differ in the use and the intensity of the aid. In general tax credits are mostly used to encourage short-term applied research, while direct subsidies are more targeted to foster long-term research (David et al., 2000; OECD, 2010).

In Spain, around 20\% of business R\&D expenditures (BERD) are funded with public support, mainly through direct aid (17-18\% of the BERD in 2007-2009, Heijs, 2011). In particular, the data from the Panel of Technological Innovation (PITEC) shows that around 30\% of Spanish innovative companies had access to public subsidies to finance their R\&D expenditures during the 2000s. ${ }^{1}$ These subsidies came principally from Spanish administrations, although a non-negligible percentage of innovative firms had also access to funds of the European Union (EU).

As for national support, between years 2002 and 2005, two national plans of R\&D were implemented: the Fourth Plan (2000-2003) and the Fifth Plan (2004-2005). In both Plans a key objective was that Spanish firms generated products and services with a greater technological component that reinforced their competitiveness. The actions of the Plans were developed by mapping agencies managers to priority areas. There was an ex-ante evaluation for the selec-

\footnotetext{
${ }^{1}$ The Spanish National Institute of Statistics constructs this database on the basis of the annual Spanish responses to the Community Innovation Survey. The survey is targeted to manufacturing and services companies whose main economic activity corresponds to sections C, D, and E of NACE 93, except non-industrial companies because of the imprecision of methodological marking in the international context by other branches of activity.
} 
tion of the proposals which was performed in two phases, one external and one internal. In the case of technological innovation projects, most of the direct R\&D support was channelled through the CDTI, and the CDTI's main instrument to support R\&D projects consisted of credits at a preferential interest rate (below the market rate).

Specifically, during the period 2002 to 2005 this agency financed three types of projects developed by firms: Technological Development Projects (TDP), Technological Innovation Projects (TIP) and Joint Industrial Research Projects (JIRP). The allocation of a proposal to one of these types was determined by the character of the R\&D that is embodied in each project. Both the TDP and the TIP have an applied character and are developed by firms, with or without the collaboration of technological centres. The difference between them is that the former implies the creation or the significant improvement of a process, good, or service, and the latter consists of the incorporation and the active adaptation of rising technologies within the firm or new markets. In the case of JIRP, the main objective is to finance initiatives of pre-competitive research presented by industrial firms in collaboration with universities, public research organizations, and/or Spanish centres of innovation and technology.

For the three types of projects, the CDTI provided financing with a zero interest rate and a period of repayment of up to 10 years, regardless of the firm activity sector and size. The quantity of the loan could reach $60 \%$ of the total budget. The CDTI only backed projects that were technically and economically viable, but did not demand real guarantees from the promoting company for the awarding of its loans. For the selection of projects, the CDTI specified the following general criteria: (a) Degree of fulfilment of the information required; (b) Scientific-technical quality of the proposal and degree of innovation; (c) The firm's technical and financial capability to undertake the project; (d) The firm's ability to exploit the results; (e) Potential market of the developments to be achieved; and (f) Fulfilment of encouraging effect. Note that these criteria are compatible with any of the potential goals discussed in the previous section (correcting market failures, fostering national champions or helping firms to upgrade), although they seem to be more focused on stimulating R\&D excellence. Once R\&D projects were approved, the CDTI monitored their development, verifying that these met the technological objectives and that the budget was properly executed, before disbursing all the funds granted.

Although we have pointed out some differences between TDP, TIP and JIRP, the common features are more remarkable from the point of view of the financial conditions and projects' 
evaluation, so the three programs are jointly considered as a unique type of funding in the following sections.

Regarding supra-national support, during the same period, Spanish firms got financing mainly through the $6^{\text {th }}$ Framework Programme (FP) of the EU (2002-2006). In general, the FP supported complex- and large-scale projects - science oriented and selected by criteria of excellence. Therefore, participants needed to have a certain level of technical and organisational capabilities. In addition, to encourage inter-European cooperation, firms and/or institutions from several countries must participate in order to be supported.

As for the tax credits system, Spanish R\&D fiscal treatment has a mixed design that combines the deduction by volume and by increase, and that is applicable to most of the costs generated by R\&D investments, including wages, raw materials, R\&D hired externally and assets amortization. ${ }^{2}$ However, it is the tax authority that recognizes such expenses as eligible costs. The proportion of deductible $R \& D$ expenditure has increased over time, going from $10 \%$ in the early 1980 s to $50 \%$ over the past years. Firms with R\&D subsidies can also claim tax credits on the R\&D expenditure remaining after subtracting $65 \%$ of the subsidies received.

Unfortunately, we cannot consider indirect public support in our analysis because we do not have access to information related to R\&D tax credits in our database. This can limit the results of our analysis as, nowadays, the Spanish tax system is considered one of the most generous among OECD countries in terms of the tax subsidy rate (OECD, 2012). ${ }^{3}$

\section{EMPIRICAL MODEL AND THE DATA}

Following the literature on impact assessment of R\&D policies, the implicit question to answer is what the behaviour of a supported firm would have been if it had not received this public aid. The problem is that each firm can only be observed either in the status of receiving the support or not. Therefore, to measure the effect of public aid on technological capability, we have to take into account that participation within a funding programme agency probably

\footnotetext{
${ }^{2}$ See more information on the design, scope and approval of R\&D tax incentive relief for OECD countries and selected economies in OECD (2015). See also Arestei et al. (2015) for a comparative study of the effects of public support on business R\&D across five European countries: France, Germany, Italy, Spain, and the UK.

${ }^{3} \mathrm{~A}$ nice exercise associating the use of $\mathrm{R} \& \mathrm{D}$ subsidies and tax incentives by Spanish firms with financing constraints can be found in Busom et al. (2014). They conclude that direct funding and tax credits are not perfect substitutes in terms of their ability to reach firms experiencing barriers associated to market failures.
} 
depends on the same firm characteristics that determine innovative performance. That is, it is necessary to take into account both selection and endogeneity problems.

Econometric literature has developed several methods in order to solve these difficulties (Heckman, 1979; Aerts et al., 2006; Guo and Fraser, 2010; Cerulli and Potì, 2012). In this paper, we employ two of the most used methodologies: a Heckman's treatment effect model and an econometric matching procedure.

As for the first method, initially a selection equation for the participation status is estimated for each of the three programmes considered in our analysis: the CDTI programme of lowinterest loans, the Spanish programme of R\&D subsidies and the Framework Programme of the European Commission. ${ }^{4}$ Specifically, our first equation is devoted to the participation of firm $i(i=1 \cdots N)$ in public funding programme $m(m=1,2,3)$ during year $t(t=1 \cdots T)$ and is formalised in terms of a multivariate model given by:

$$
y_{m i t}=\left\{\begin{array}{l}
1 \text { if } y_{m i t}^{*}=x_{m i t} \beta_{m}+u_{m i t}>0 \\
0 \text { otherwise }
\end{array}\right.
$$

where $y_{m i t}^{*}$ is a latent dependent variable, $x_{m i t}$ is the set of explanatory variables that can differ across equations, $\beta_{m}$ is the vector of coefficients and $u_{m i t}$ are the error terms distributed as multivariate normal, each with a mean of zero, and variance-covariance matrix $V$, where $V$ has a value of 1 on the leading diagonal and correlations $\rho_{j k}=\rho_{k j}$ as off-diagonal elements:

$$
\left(\begin{array}{l}
u_{1 i t} \\
u_{2 i t} \\
u_{3 i t}
\end{array}\right) \approx N_{M}\left[\left(\begin{array}{l}
0 \\
0 \\
0
\end{array}\right),\left(\begin{array}{ccc}
1 & \rho_{12} & \rho_{13} \\
\rho_{12} & 1 & \rho_{23} \\
\rho_{13} & \rho_{23} & 1
\end{array}\right)\right]
$$

In the second step, we analyse the impact of this participation on the R\&D intensity of the firms. Following the approach of Griffith et al. (2006), we believe that, to some extent, all firms make some innovative effort. However, below a certain threshold, the firm is not capable of picking up explicit information about this effort and will not report on it. Thus, we estimate a selection model for the observed R\&D intensity. In particular, we think that we can measure R\&D effort $i d_{i t}^{*}$ by the intensity of $R \& D$ expenditure $i d_{i t}$ only if the firm makes and

\footnotetext{
${ }^{4}$ We have information only about financed projects and therefore we cannot distinguish between the firm's decision to apply for the aid and the agency selection among the proposals. The main disadvantage of this lack of information is that the selectivity problem is not fully considered.
} 
reports that expenditure. To represent this decision to perform and report R\&D expenditures, we assume the following selection equation:

$$
r_{i t}=\left\{\begin{array}{ll}
1 & \text { if } r_{i t}^{*}=\sum_{m=1}^{3} p_{m i t} \gamma_{1 m}+z_{1 i t}^{\prime} \delta_{1}+\varepsilon_{1 i t}>0 \\
0 & \text { otherwise }
\end{array},\right.
$$

where $r_{i t}$ is a binary variable that takes the value 1 when the firm invests in (and reports) $\mathrm{R} \& \mathrm{D}$, and 0 otherwise. If the latent variable $r_{i t}^{*}$ is bigger than a constant threshold (which can be zero), we then observe that the firm engages in (and reports) R\&D activities. In this equation, $p_{m i t}$ denotes the predicted value for the probability of participating within a public funding programme, $\gamma_{m}$ is the parameter that reflects the impact of the different public aid programmes, $z_{1 i t}$ is a vector of observable explanatory variables, and $\varepsilon_{1 i t}$ is an idiosyncratic error.

Conditional on the performance (and reporting) of R\&D activities, we can observe the quantity of resources allocated to this purpose; that is,

$$
i d_{i t}=\left\{\begin{array}{ccc}
i d_{i t}^{*}=\sum_{m=1}^{3} p_{m i t} \gamma_{2 m}+z_{2 i t}{ }^{\prime} \delta_{2}+\varepsilon_{2 i t} & \text { if } & r_{i t}=1 \\
0 & \text { if } & r_{i t}=0
\end{array},\right.
$$

where $z_{2 i t}$ is a vector of determinants of the innovative effort, which can differ from those determinants that explain the decision to perform and report R\&D expenditures, and $\varepsilon_{2 i t}$ is the error term.

Therefore, we estimate a Heckman model, assuming that the error terms $\varepsilon_{1 i}$ and $\varepsilon_{2 i}$ follow a bivariate normal distribution with a mean equal to 0 , variances $\sigma_{1}^{2}=1$ and $\sigma_{2}^{2}$, and correlation coefficient $\rho_{12}$. This structure allows us to analyse whether the impact of public aid differs across programmes, not only in the decision to undertake innovation activities but also in R\&D intensity. However, due to restrictions in data availability, we cannot define measures of R\&D intensity net of the received public aid. Therefore, through the estimation of equation [3] we can only test the hypothesis of full crowding-out, that is, total substitution between private and public R\&D expenditures. We cannot test the so-called 'additionality' hypothesis, that is, we cannot measure the effect induced in company-financed $R \& D$ expenditures per euro of public support. 
Notice that, in equations [2] and [3], to deal with the selection (and endogeneity) problem, the predicted probability of participation in each public programme is considered instead of the observed participation status. The economic rationale for this strategy is that we believe that the latent variable in equation [1] can be interpreted as the agency's expectation about the returns of the project or, at least, about its adjustment to the targets of the public programme. In this sense, the prediction of the observed participation status would be a suitable instrumental variable for the unobservable latent variable. In this way, we not only take care that the participation is possibly endogenous, but we also qualify the relevance of the project for the public agency. ${ }^{5}$

One disadvantage of this methodology is that it relies on very parametric assumptions, as it implies both linearity and errors' joint normality. In addition, given that the predicted probabilities of participation are generated from the same set of explanatory variables, their joint inclusion in equations [2] and [3] would imply a problem of multicollinearity, preventing the analysis of the effect of multiple treatments.

Therefore, we complement this analysis performing a matching procedure that does not require any functional form or a distributional assumption on the errors of equations [2] and [3]. However, we need to assume that all firm characteristics explaining the selection into a public funding program are observed (that is, the conditional independence assumption has to hold). Specifically, we follow the methodology by Gerfin and Lechner (2002), which is based on nearest neighbor matching and which has been used by Czarnitzki et al. (2007) and Czarnitzki and Lopes-Bento (2014) to consider multiple treatments in other innovation-related contexts.

In our case, initially we defined eight mutually exclusive states of public funding: no public funding, only CDTI loan, only national subsidy, only EU subsidy, CDTI loan and national subsidy (but not EU subsidy), CDTI loan and UE subsidy (but not national subsidy), national and European subsidies (but not CDTI loan), and all types of public funding. This leads to 56 possible combinations of treatments (see Table A.1 of Appendix.2). However, the effects of some of them could not be estimated due to data limitation (see Section 4.1 for more details on our data). Specifically, this problem appeared when one of the treatments involved in the combination was ‘CDTI loan and European subsidy' or 'All types'.

\footnotetext{
${ }^{5}$ Other studies that use this type of pseudo-instrumental variables approach in similar frameworks are Griffith et al. (2006), Huergo and Moreno (2011), and Barajas et al. (2012, 2016).
} 
For this reason, in this part of our analysis we decided to focus on CDTI loans as policy tool, studying national and European subsidies as potentially complementary schemes. In particular, to facilitate the discussion, we distinguish among the cases of public funding shown in Table 1. Note that the treatment denoted as 'only subsidies' refers to firms that have been awarded a national subsidy and/or a European grant, but not a CDTI loan. In the same line, the treatment with the label of 'CDTI loans \& subsidies' stands for firms that meet any of the following situations: having a CDTI loan and a national subsidy, obtaining a CDTI loan and a European subsidy, or being financed through the three programmes.

Table 1: Cases of matching

\begin{tabular}{cllccc}
\hline \hline & & & \multicolumn{2}{c}{ Number of observations } \\
\cline { 3 - 5 } Case & Actual status & Counterfactual & Total & $\begin{array}{c}\text { Treated } \\
\text { group }\end{array}$ & $\begin{array}{c}\text { Control } \\
\text { group }\end{array}$ \\
\hline A & Only CDTI loan & No public funding & 1112 & 571 & 541 \\
B & Only national subsidy & No public funding & 1376 & 707 & 669 \\
C & Only European subsidy & No public funding & 280 & 143 & 137 \\
D & Only subsidies & No public funding & 1715 & 868 & 847 \\
E & CDTI loans \& subsidies & No public funding & 728 & 375 & 353 \\
F & Only national subsidy & Only CDTI loan & 678 & 337 & 341 \\
G & Only European subsidy & Only CDTI loan & 187 & 95 & 92 \\
H & Only subsidies & Only CDTI loan & 749 & 336 & 413 \\
I & CDTI loans \& subsidies & Only CDTI loan & 516 & 267 & 249 \\
J & Only European subsidy & Only national subsidy & 242 & 123 & 119 \\
K & CDTI loans \& subsidies & Only subsidies & 634 & 321 & 313 \\
\hline \hline
\end{tabular}

Note: Observations for total, treated and control samples are obtained after applying the matching procedure (see Appendix 3).

As is well-known, the problem in this kind of analysis is that, for each firm receiving a specific treatment (actual status), we can only observe the actual R\&D intensity. Therefore, we need to create the counterfactual, that is, we need to construct a control sample of firms with characteristics similar to those of the treated group. Following the methodology by Gerfin and Lechner (2002), these nearest neighbors are selected based on propensity scores of receiving a certain treatment. The specification used to compute this propensity score is based on all explanatory variables included in the multivariate probit depicted for the estimation of equation [1]. For each treated firm, we search for a firm in the counterfactual group that had the same probability of receiving the treatment but did not actually get it. The average treatment effect is estimated by the mean difference in the variable of the matched pairs. 
For example, the case A allows us to analyse how R\&D intensity of firms that only obtained a CDTI loan would vary if they have not been funded at all. We also test whether the different types of public funding have the same impact when they are separately awarded (cases A, B and $\mathrm{C}$ ), and we compare to the joint effects of participating in different policy schemes as opposed to single scheme use (cases F to K).

The detailed explanations about the matching procedure and the tests that we use to assess the performance of the propensity score matching can be found in Appendix 3.

\subsection{The database}

As we mentioned in the introduction, two data sources are used in this paper. The first one is the CDTI database of low-interest loans for R\&D projects for the period 2002-2005. Specifically, we analyse 1,787 projects which were granted a low-interest loan by the CDTI during this period. These data are especially suitable for our analysis as most of the direct R\&D support from the Spanish central government is channelled through the CDTI, and the CDTI's main instrument during this period consists of loans at a preferential interest rate.

This information has been completed with a database that was provided by the National Institute of Statistics (INE) and corresponds to a sample of innovative firms from the Spanish Technological Innovation Survey. In this survey, we find complementary information about sources of public financial support for innovation activities from the different levels of government. These data from the INE were anonymized for some variables, so firms from the sample could not be identified. As a consequence, the magnitude of the subsidies and loans is unknown. Therefore, as we have already mentioned, we cannot define measures of R\&D intensity net of the received public aid, and only total substitution between private and public R\&D expenditures can be tested.

For the estimations we have eliminated 48 observations with a ratio of $R \& D$ expenditures over sales bigger than 10 (more than $1000 \%$ ); these relate mainly to new firms which have initiated their technological activities but have not yet begun to sell their products or services. The final sample consists of an unbalanced panel with 4,407 firms (13,546 observations).

As can be seen in Table 2, around 50\% of the firms do not obtain any type of public funding in the period, while less than $3 \%$ of firms are supported through the three schemes. In these sense, notice that our sample is slightly biased towards innovative firms, which have a higher 
propensity to apply for public funding. In particular, more than $45 \%$ of the firms are supported by national programmes (CDTI loans and national subsides). However, the percentage of companies with European public funding is less than $10 \%$.

Table 2: Distribution of the sample by type of public funding. 2002-2005

\begin{tabular}{lrlr}
\hline \hline & Yearly observations & \multicolumn{1}{c}{$\begin{array}{c}\text { Firms } \\
\text { (in period 2002-2005) }\end{array}$} \\
\hline No public funding & $9,662(70.1 \%)$ & $2,222(50.4 \%)$ \\
Only CDTI loan & $1,108(8.2 \%)$ & $635(14.4 \%)$ \\
Only national subsidy & $1,451(10.7 \%)$ & $483(11.0 \%)$ \\
Only European subsidy & $322(2.4 \%)$ & $160(3.6 \%)$ \\
CDTI loan \& national subsidy & $587(4.3 \%)$ & $624(14.2 \%)$ \\
CDTI loan \& European subsidy & $32(0.2 \%)$ & $25(0.6 \%)$ \\
National \& European subsidies & $324(2.4 \%)$ & $144(3.3 \%)$ \\
All types of public funding & $60(0.4 \%)$ & $114(2.6 \%)$ \\
\hline
\end{tabular}

Notes: In column 1, firms are classified according to the year that they are supported or not. In column 2, firms are classified considering the whole period.

The selection of explanatory variables in the model is based on previous empirical literature and is also determined by the availability of information in our databases. As for firms' participation in public R\&D programmes (equation [1]), most papers include measures of the firm's technological profile, as the chance to apply increases when the propensity to perform $R \& D$ projects is higher. ${ }^{6}$ The available information allows us to consider several variables. The first one is internal $R \& D$ intensity, which we compute as the ratio of internal $R \& D$ expenditures over total employment. We also define total R\&D intensity as total (internal plus external) R\&D expenditures per employee. In our sample, the means of these variables are greater in firms that have been awarded a European subsidy than in firms with a national subsidy, and superior in these nationally-subsidized firms than in firms with a CDTI loan (see Table 3 ). ${ }^{7}$

\footnotetext{
${ }^{6}$ See, for instance, Blanes and Busom (2004), González et al. (2005), Heijs (2005), Clausen (2008) or Huergo et al (2016).

${ }^{7}$ In Appendix 1, we present the definitions of the variables, and in Table A.2 of Appendix 2 we show their main descriptives for the whole sample.
} 
Table 3: Means of main variables by type of public funding

\begin{tabular}{|c|c|c|c|c|c|c|c|c|}
\hline & \multirow[b]{2}{*}{ All firms } & \multirow{2}{*}{$\begin{array}{c}\text { Non-supported } \\
\text { firms } \\
(1) \\
\end{array}$} & \multicolumn{3}{|c|}{ Supported firms } & \multicolumn{3}{|c|}{ " Difference of means test ${ }^{\text {a) }}$} \\
\hline & & & $\begin{array}{c}\text { CDTI } \\
\operatorname{loan}(2)\end{array}$ & $\begin{array}{c}\text { National } \\
\text { subsidy (3) }\end{array}$ & $\begin{array}{l}\text { European } \\
\text { subsidy (4) }\end{array}$ & (1) vs (2) & (1) vs (3) & (1) vs (4) \\
\hline $\begin{array}{l}\text { Technological characteristics } \\
\text { - Internal R\&D intensity (K€ per employee) (in logs.) } \\
\text { - Internal R\&D performer }(0 / 1) \\
\text { - Patent application }(0 / 1) \\
\text { - Percentage of R\&D employees }(\%) \\
\text { - R\&D performer (internal or external) }(0 / 1) \\
\text { - Technological cooperation }(0 / 1) \\
\text { - Total R\&D intensity (K€ per employee) (in logs.) } \\
\text { - High and medium-tech manufacturing }(0 / 1) \\
\text { - High and medium-tech services }(0 / 1) \\
\text { Other firm characteristics } \\
\text { - Belonging to a group }(0 / 1) \\
\text { - Exporter }(0 / 1) \\
\text { - Foreign capital }(0 / 1) \\
\text { - Public firm }(0 / 1) \\
\text { - Relative labour productivity } \\
\text { - Size (Number of employees) } \\
\text { - Start-up }(0 / 1) \\
\text { Number of observations }\end{array}$ & $\begin{array}{c}6.7 \\
0.592 \\
0.170 \\
43.1 \\
0.625 \\
0.340 \\
8.2 \\
0.235 \\
0.096\end{array}$ & $\begin{array}{c}3.2 \\
0.450 \\
0.129 \\
32.0 \\
0.492 \\
0.245 \\
4.3 \\
0.193 \\
0.073 \\
\\
0.392 \\
0.511 \\
0.122 \\
0.019 \\
0.998 \\
375.0 \\
0.021 \\
9.662\end{array}$ & $\begin{array}{c}12.8 \\
0.879 \\
0.284 \\
66.4 \\
0.901 \\
0.495 \\
15.2 \\
0.412 \\
0.103 \\
\\
0.467 \\
0.714 \\
0.113 \\
0.008 \\
1.028 \\
268.0 \\
0.060 \\
1.764\end{array}$ & $\begin{array}{c}16.6 \\
1.000 \\
0.304 \\
73.4 \\
1.000 \\
0.650 \\
19.8 \\
0.330 \\
0.175 \\
0.429 \\
0.656 \\
0.095 \\
0.024 \\
0.989 \\
329.9 \\
0.055 \\
2.422\end{array}$ & $\begin{array}{c}25.9 \\
1.000 \\
0.292 \\
79.4 \\
1.000 \\
0.690 \\
28.9 \\
0.249 \\
0.247\end{array}$ & $\begin{array}{l}0.000 \\
0.000 \\
0.000 \\
0.000 \\
0.000 \\
0.000 \\
0.000 \\
0.000 \\
0.000 \\
0.000 \\
0.000 \\
0.281 \\
0.001 \\
0.475 \\
0.000 \\
0.000\end{array}$ & $\begin{array}{l}0.000 \\
0.000 \\
0.000 \\
0.000 \\
0.000 \\
0.000 \\
0.000 \\
0.000 \\
0.000 \\
0.000 \\
0.000 \\
0.000 \\
0.162 \\
0.888 \\
0.053 \\
0.000\end{array}$ & $\begin{array}{l}0.000 \\
0.000 \\
0.000 \\
0.000 \\
0.000 \\
0.000 \\
0.000 \\
0.000 \\
0.000 \\
0.017 \\
0.002 \\
0.013 \\
0.000 \\
0.254 \\
0.000 \\
0.049\end{array}$ \\
\hline
\end{tabular}

Notes: The symbol $(0 / 1)$ means dummy variable. ${ }^{a}$ : $p$-value of a two-sample difference of means test. This test is a t-test for continuous variables and a two-sample z-test of proportions in case of dummy variables. 
In addition, we introduce an indicator reflecting whether the firm has technological cooperative agreements. We can distinguish between the kinds of partners, which can be clients, providers, competitors, consultants and laboratories, other firms of the group, universities, public research centres (PRCs) and technological centres. As can be seen in Table 3, the sample mean of these indicators is higher for participants in public R\&D programmes than for nonawarded firms. We also consider the prior application for patents that can reflect the firm's technological and commercial success in the past. Again, the sample mean of this variable is higher for participants in national and European R\&D programmes than in non-supported firms.

Regarding the sectorial dimension, we define industry dummies at NACE 2-digit level to take into account the possibility of differing technological opportunities across sectors. As can be seen in Table A.3 of Appendix 2, regardless of the type of public aid, supported firms are relatively more present in high and medium-tech sectors. In addition to the variables that reflect technological features, we also consider in our specification other firms' characteristics that can affect their participation in public R\&D programmes. In this sense, the firm's size is a usual determinant in most papers which deal with the impact of public funding. However, its effect on participation is not clear. SMEs are usually more affected by innovation-related market failures, so their benefits from public aid could be higher. However, large firms usually have more resources with which to undertake R\&D projects and apply for the aid. In addition, public agencies can be too risk-averse to finance R\&D of small firms.

Statistics in Table 3 show that firms awarded by the CDTI and firms supported by national subsidies are smaller than non-supported companies. However, firms supported by European subsidies are bigger than non-participants in public systems. Most observations of the sample refer to firms which have between 10 and 50 employees $(33.8 \%)$ and large firms, with more than 200 workers $(33.9 \%)$.

A second dimension frequently considered in the literature is the age of the firm. Again, its expected effect on participation is ambiguous. More experienced firms (older firms) are more likely to use public aid. However, young firms tend to be more financially constrained and, as a consequence, they could apply for and receive public aid more frequently. The information in our databases allows us to know whether the firm was born during the last three years. If this is the case, we consider the firm to be a start-up. Table 3 shows that the percentage of 
start-ups is higher among firms supported by national and international agencies, especially by the CDTI.

Another aspect that should be taken into account is the firm's competitive position in the reference market, which could be captured by its market share, the evolution of sales or the exporting activity. The key question here is what to expect. Will firms with more market power participate more in public programmes? Regarding international competition, the expected answer for exporters would be affirmative, for at least two reasons. Their position in international markets could be a signal of their ability to transform innovations into successful products (Czarnitzki and Licht, 2006). Also, they could be facing lower application costs as they are more experienced in dealing with bureaucracy compared to non-exporters (Takalo et al., 2013). In our sample, the presence of firms with foreign activity is higher among supported firms, especially by the CDTI (see Table 3 ).

Finally, additional control variables are introduced. Time dummy variables are included, allowing for business cycle effects or changes in national and European agencies' budgets. As an indicator of the ease of access to external capital markets, possibly meaning better knowledge of the public aid system, a dummy variable representing the presence of foreign capital among shareholders is incorporated. As can be seen in Table 3, there are no significant differences between non-funded firms and participants supported by the soft loan system. For the same reason, an indicator of business group membership for each firm is considered. Agencies might be less willing to finance firms which belong to a group because it is expected that these firms benefit from the group in terms of having fewer financial restrictions. And a dummy variable that represents the presence of public capital is incorporated. Notice that a higher proportion of public firms are supported by the European agency.

With respect to the decision to engage in $R \& D$ investment and the determinants of the intensity of the R\&D (equations [2] and [3]), the theoretical literature suggests including variables related basically to technological environment, market conditions, financial constraints, appropriability of technological returns and size (reflecting R\&D economies of scale) as determinants (see, for example, Arvanitis and Hollenstein, 1994; Klepper, 1996).

To capture environmental and demand conditions, we have considered one indicator of the firm's export character, the export intensity and time dummies. We expect that firms operat- 
ing in competitive international markets have more incentives to innovate and therefore to invest in R\&D.

As for financial restrictions, the high level of risk of R\&D projects and the existence of information asymmetries between firms and suppliers of external finance increase the firms' dependence on internal funds (Hall, 2002). Therefore, firms with liquidity constraints are expected to have more difficulties undertaking R\&D projects. The evidence about the impact of financial restrictions on investment effort is mixed. Previous studies for the Spanish economy point out that, since 2000, the investment effort has been superior in firms that won public support than in those which applied for it without success, and greater in the latter than in firms that did not apply for it. Unfortunately, we do not have information about firms' financial conditions in our database. ${ }^{8}$ However, given the aim of this paper, special attention is devoted to a firm's participation in the CDTI low-interest loan programme and national and European innovation subsidies schemes. These public aid instruments could increase the chances of performing $\mathrm{R} \& \mathrm{D}$, as tools that reduce a firm's financial constraints.

To indicate appropriability conditions, we use a measure of relative labour productivity and the proportion of R\&D employees in the firm as a proxy of human capital. We think that those firms more productive and with more qualified personnel are more capable of assimilating new knowledge, whether it is developed internally or externally. Piva and Vivarelli (2009) provide evidence that supports this hypothesis for a panel of Italian firms. As expected, and as can be seen in Table 3, supported firms present a higher percentage of R\&D employment than non-financed firms. Nevertheless, there is no difference in relative labour productivity between these two groups of companies.

In addition, following previous papers for the Spanish economy, we introduce industry dummies that can also approximate sectorial technological opportunities and appropriability conditions (Beneito, 2003; Ortega-Argilés et al., 2005). Specifically, we included the dummies for firms that belong to high and medium-tech sectors.

Along with the above variables, the specification includes indicators to capture differences in the firms' investment behaviour in terms of the time of permanence in the market. In

\footnotetext{
${ }^{8}$ The Spanish Technological Innovation Survey includes information about the relative importance assigned by firms to the lack of funds in the firm or group, the lack of external financing or the existence of high innovation costs as factors that hamper innovation. However, this information was not provided in the selection of variables that the INE gave us to do this research.
} 
particular, an indicator of newly born firms (start-ups) is included. Empirical evidence suggests that start-ups are usually among the most innovative firms; their survival probability as well as their growth rate depends strongly on their innovative behaviour (Audretsch, 1995; Huergo and Jaumandreu, 2004). Finally, as in equation [1], we include as control variables some factors related to firms' organisational aspects: belonging to a group, foreign capital, public capital and technological cooperation.

\section{RESULTS}

In this section, we present the results of our treatment effects analysis. We begin with the explanation of participation in public aid programmes. Later, we analyse how participation in these programmes affects the R\&D activities of the firms.

\subsection{The determinants of participation in public $R \& D$ programmes}

Table 4 shows the estimation of the determinants of firms' participation in public aid programmes. Considering that we have information about three systems of public aid, we use a multivariate probit model (seemingly unrelated probit model). ${ }^{9}$ Some of the explanatory variables are included with one lag in the estimates to avoid direct simultaneity.

As expected, the correlation coefficients $\rho_{21}$ and $\rho_{32}$ are significantly different from zero and positive. In accordance with Busom and Fernández-Ribas (2007) and Czarnitzki and LopesBento (2014), national support and European funding are positively linked to each other. The same happens with soft loans and national subsidies, indicating the presence of common unobserved factors that affect the probability of participating in both programmes. A positive shock on the likelihood of being awarded an EU grant and a CDTI loan would also translate into a positive shock in the probability of getting a national subsidy. However, $\rho_{31}$ is nonsignificant, implying that there are no common unobserved factors affecting the probabilities of participating in the national soft loan system and the scheme of European subsidies. At this respect, in our very short panel most of non-supported firms in one year remain in the same status the following year, while awarded firms tend to change the specific type of public aid they achieve from one period to the next (see Table A.4 of Appendix 2). In this sense, transition rates across participation status do not suggest any clear pecking order in which firms make use of the different support channels.

\footnotetext{
${ }^{9}$ See Cappellari and Jenkins (2003).
} 
Table 4: Participation in public R\&D programmes. Multivariate Probit model

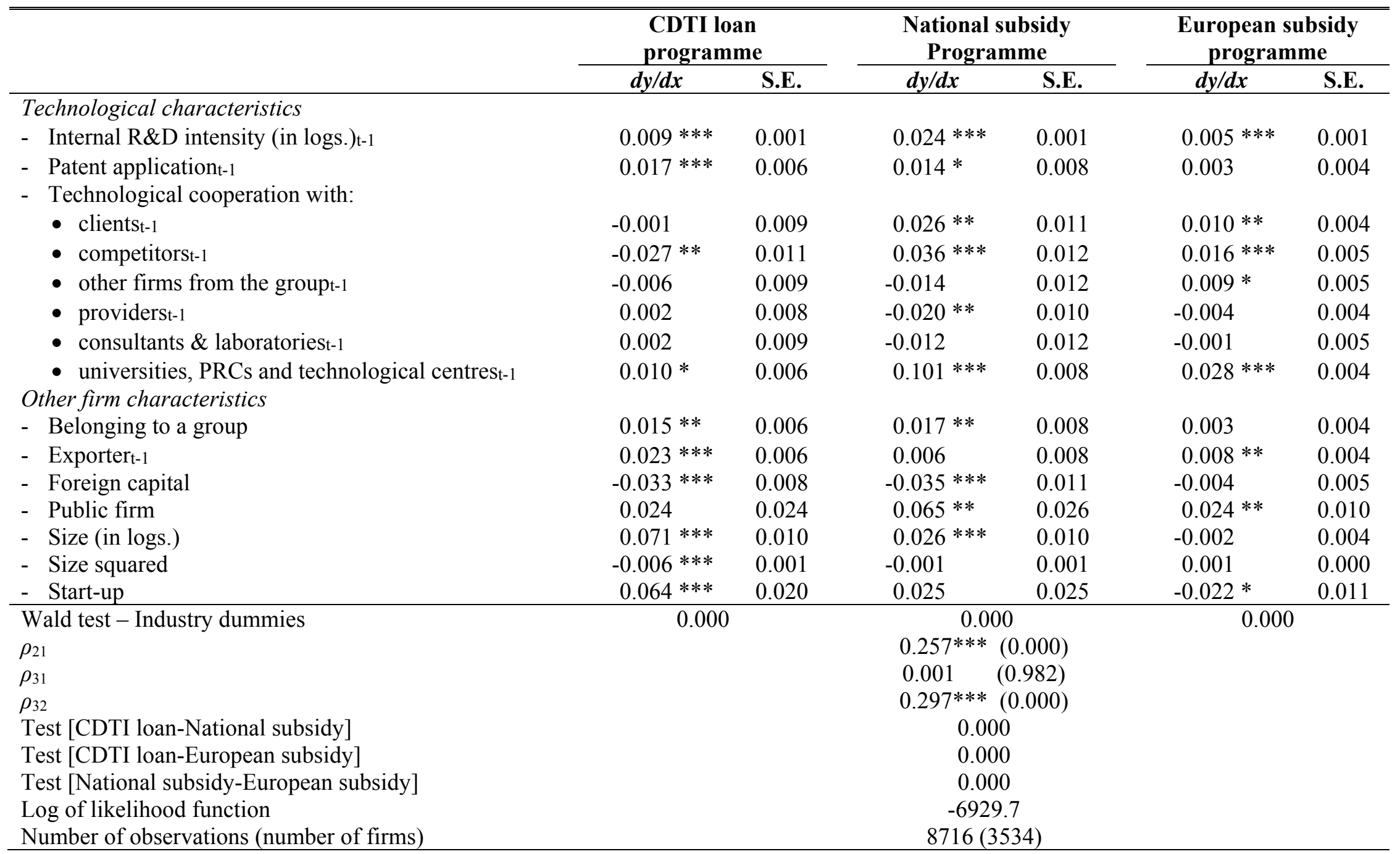

Notes: S.E.: Standard errors. Coefficients significant at $1 \% * * *, 5 \% * *, 10 \% *$. Marginal effects $(d y / d x)$ are computed at sample means. (t-1) denotes that the variable is included with one lag. All regressions include a constant, time dummies for the years 2003 and 2004 and industry dummies at NACE 2-digit level. To avoid multicolinearity, the dummy variables corresponding to year 2002 and industry 1 (Agriculture) are excluded. Wald test reports the p-value of a test of joint significance of industry dummies. Test reports the p-value of a test of equality of coefficients. $\rho_{21}, \rho_{31}$ and $\rho_{32}$ (p-values in parentheses) are the correlation coefficients across equations 
As for the explanatory variables, most of them are statistically significant and their marginal effects have the same sign in all columns. The Wald tests for industry dummies at NACE 2digit level show that all of them are jointly significant. However, the joint chi-square test clearly rejects the equality of coefficients across equations ( $p$-value $=0.000$ ). This result implies that globally the participants within the three systems of public aid have different characteristics, suggesting that the programmes do not completely overlap in terms of their recipients.

The first fact that can be highlighted from Table 4 is the positive effect of having a higher technological profile on the probability of participation in all public aid programmes. The internal $R \& D$ intensity of the previous year has a statistically positive impact for all kinds of funding. Looking at the magnitude of marginal effects, the participation in national subsidy programmes reacts more sensitively to prior innovation experience than in the CDTI loan system.

Being a patent applicant in the previous year also positively affects the chance of participation in the soft loan and national subsidy systems. It seems that the CDTI is especially sensitive to the previous technological success of candidate firms in order to award a loan. These results are in accordance with the evidence provided by Huergo et al. (2016) for the same loan system. They are also in accordance with Liu and Rammer (2016) who find that patent stock is highly significant and positive in explaining the probability of receiving public funding.

In addition, having technological agreements in general increases the probability of obtaining European funding. This result is coherent with the objectives of the Framework Programme, which promotes cooperation between firms of different countries. The European agency is especially sensitive to cooperation with competitors and with universities, PRCs and other technological centres. A similar effect is obtained for participation in the national funding programme with the exception of the cooperation with providers. Our results are in accordance with García and Mohnen (2010), who find that Austrian firms which cooperated in innovation were more likely to get help from both national and EU sources during the period 1998-2000. A similar result is obtained by Hottenrott and Lopes-Bento (2014) for Belgian firms but only for small and medium firms which cooperate with foreign firms. However, technological cooperation does not seem to increase the propensity to participate in the soft loan programme. Only cooperation with universities, PRCs and other technological centres has a positive and significant impact, while cooperation with competitors shows a negative 
effect. Nevertheless, these results should be interpreted with caution because of the high correlation among the different types of collaboration partners in our survey data (see table A.5 of Appendix 2).

As for the rest of the firms' characteristics, being an exporter in the previous year increases the probability of participating in the CDTI low-interest loan system and the European subsidy system but does not affect participation in the national subsidy programme. The presence of foreign capital has a negative effect for obtaining national funding. This result suggests that the national government and the CDTI are more reluctant to finance firms that belong to foreign groups than to domestic ones. García and Mohnen (2010) and Czarnitzki and LopesBento (2014) also find a negative effect of this variable on European funding, but in our sample, we do not find this result. Group membership does not have a significant effect on European subsidies.

Another interesting result in Table 4 is the existence of a non-linear effect of size on the probability of participating in the CDTI low-interest loan system. As firms are larger, they have a higher probability of being awarded by the CDTI, but the increase in size affects the probability of obtaining financing marginally less. This result, which is in accordance with Huergo et al. (2016), suggests that applying for CDTI loans has some costs in terms of time and searching for information, so larger firms have a higher probability of participating, although as a certain amount of resources is obtained, the size effect is smaller.

Finally, being a start-up positively affects the chance of participation in the soft loan programme. Although more experienced firms are more likely to know and use public aid programmes, younger firms are usually more financially constrained, having more incentives to apply for and receive them. It seems that the second effect exceeds the first one. In the case of national subsidies it is seems that both effects compensate each other, while the negative effect prevails for European public aid.

In summary, participation within the CDTI loans system is specifically related to international market orientation and patents application. Due to the reimbursable character of this kind of public aid, it seems that technological results and performance success (measured by export activity) serve as collateral in order to be awarded. The participation in this public system is also non-linearly related to firm size. The probability of being awarded increases with the number of employees, but once firms are large enough, the marginal effect of size diminishes. 
In the case of participants within the national subsidy system, the technological profile of the firms plays the key role, specifically regarding the R\&D intensity. Participation is also associated with technological cooperation with competitors, clients and, especially, universities, PRCs and technological centres. In this case, the effect of size is strictly increasing.

Finally, Spanish participation within European subsidy programmes also tends to be related to the presence in foreign markets and the existence of technological agreements. However, applying for patents and firm' size seem to be irrelevant. In this respect, note that participation in this kind of programme usually implies the existence of self-organised consortia. In our analysis, we only have information about Spanish participants. However, firms with different characteristics can coexist in the same consortium if their resources and capabilities are complementary.

\section{2. $R \& D$ equations}

Table 5 shows the results of the estimation associated with equations [2] and [3] explained in Section 3. In these equations, the predicted value for the probability of participating within a public funding programme is introduced in percentage. Therefore, we can interpret estimated marginal effect for each programme as the increase in the probability of performing R\&D when the probability of participating within that programme increases in one percentage point.

Specifically, we present the marginal effects of the Generalized Tobit model where the participation and the intensity equations are estimated consistently by maximum likelihood. Most explanatory variables in the first equation are also considered as explanatory variables in the second equation. Due to the high correlation among the dummy variables that illustrate the different partners in technological agreements, in these estimates we consider a unique binary indicator of technological cooperation.

In order to analyse whether the determinants of internal $R \& D$ expenditures differ from the determinants of total R\&D expenditures, we present the results of the Heckman model for both internal and total R\&D intensity. Notice that the correlation term rho is significant in both estimations, pointing out the necessity of estimating a selection model for the observed intensity. 
Table 5: R\&D intensity. Generalized Tobit model

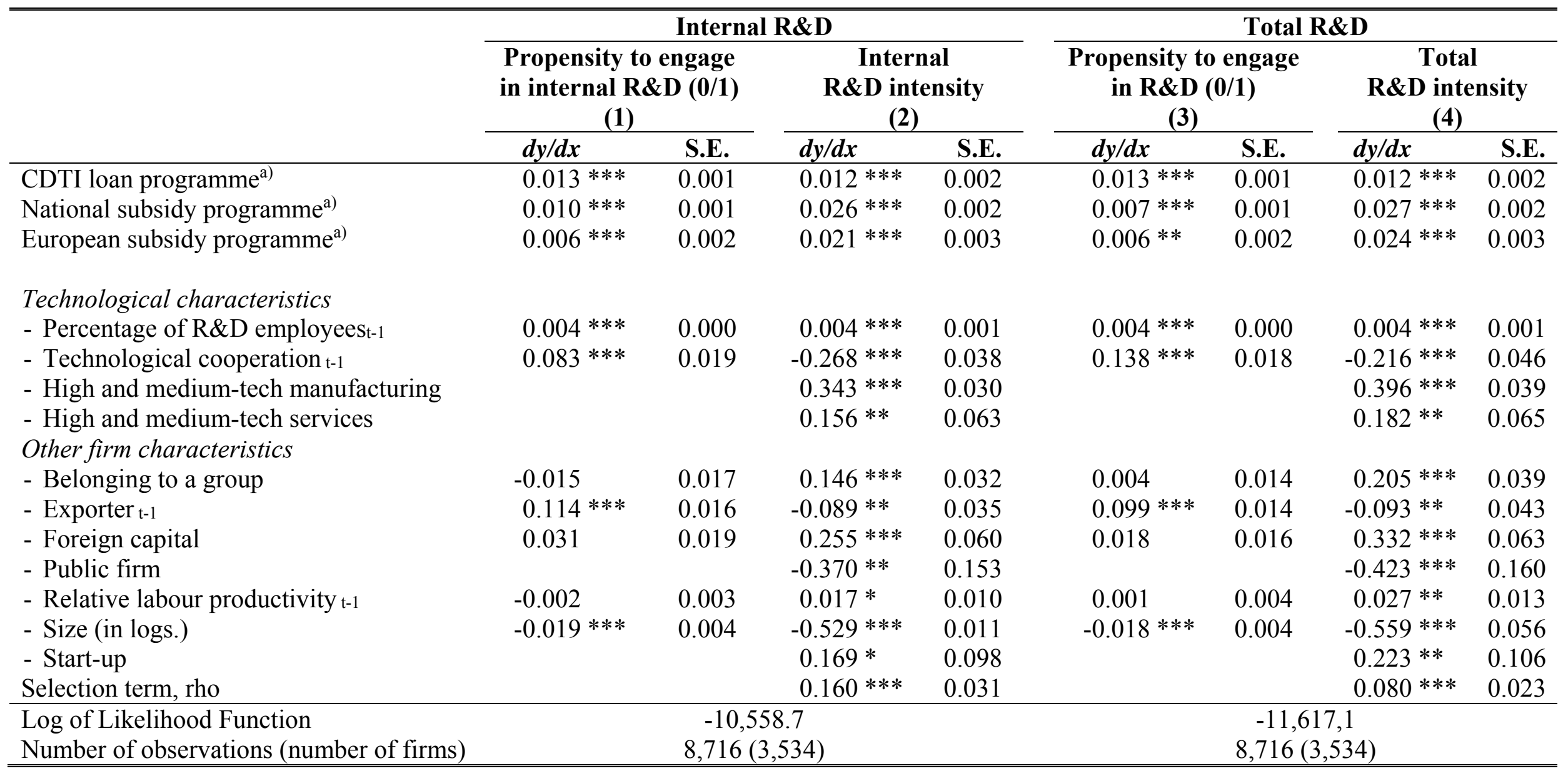

Notes: ${ }^{\text {a) }}$ The prediction of the probability of participating in each programme is obtained from Table 4 . S.E.: Bootstrapped standard errors. Coefficients significant at $1 \% * * *$, $5 \%{ }^{* *}, 10 \% *$. Marginal effects $(d y / d x)$ are computed at sample means. For dummy variables, the marginal effect corresponds to change from 0 to 1 . All regressions include a constant and time dummies for the years 2003 and 2004. 
Although it is possible to assume that most variables are exogenous, the indicators for being an exporter, technological cooperation, relative labour productivity and the percentage of R\&D employees are again introduced with a lag in the decision equation to avoid direct simultaneity. The results in Table 5 for most control variables are in line with previous literature (Ortega-Argilés et al., 2005; Griffith et al., 2006; Hall et al., 2009; Huergo and Moreno, 2011). Marginal effects have in general the expected sign in both equations.

The estimations in columns (1) and (3) also show that being awarded any type of public support clearly increases the probability of conducting R\&D activities. Participation in the three kinds of public funding systems raises the probability of self-financing internal R\&D activities. The highest impact corresponds to soft loans. Specifically, an increase in one percentage point in the probability of being supported by the CDTI loan programme increases the probability of performing internal $R \& D$ in 1.3 percentage points. The impacts are quite similar when we consider total R\&D expenditures.

With respect to magnitude of $R \& D$ expenditures, as can be seen in columns (2) and (4), once the firm has decided to invest, again the three kinds of public aid stimulate the intensity of gross R\&D investment, although the lowest impact corresponds to soft loans. European subsidies have a slightly higher impact on total $R \& D$ intensity than on internal $R \& D$ intensity. Notice also that marginal effects of subsidies are quite similar regardless of the national or supranational character of the public agency. However, we cannot interpret the differences in the magnitudes of marginal effects as differences in the degree of 'additionality' among the three programmes, as we are not comparing the R\&D intensity net of public aid of supported firms with that of non-supported firms.

If instead of introducing the three variables denoting the participation in public programmes simultaneously in the equation, we consider a separate equation for the participation in each programme (see Table 6), estimated impacts are higher in both equations (decision to engage in $R \& D$ and intensity). This evidence points out that, when we do not take into account the correlation in the participation in the three programmes, the impacts of this participation could be biased. Note that this methodology does not allow us to properly measure the isolated effect of one single instrument of public support, as the three treatments considered in this stage are not mutually exclusive. are possible simultaneously 
Table 6: R\&D intensity (in logarithms). Generalized Tobit model

\begin{tabular}{|c|c|c|c|c|}
\hline & \multicolumn{4}{|c|}{ Dependent variable: } \\
\hline & $\begin{array}{c}\text { Propensity to } \\
\text { engage in internal } \\
\text { R\&D (0/1) }\end{array}$ & $\begin{array}{c}\text { Internal } \\
\text { R\&D intensity } \\
\text { (log.) }\end{array}$ & $\begin{array}{l}\text { Propensity to } \\
\text { engage in total } \\
\text { R\&D }(0 / 1)\end{array}$ & $\begin{array}{l}\text { Total R\&D } \\
\text { intensity } \\
\text { (log.) }\end{array}$ \\
\hline CDTI loan programme a) & $\begin{array}{c}0.018 * * * \\
(0.001)\end{array}$ & $\begin{array}{c}0.023 * * * \\
(0.003)\end{array}$ & $\begin{array}{c}0.017 * * * \\
(0.001)\end{array}$ & $\begin{array}{c}0.024 * * * \\
(0.003)\end{array}$ \\
\hline National subsidy programme a) & $\begin{array}{c}0.016^{* * * *} \\
(0.001)\end{array}$ & $\begin{array}{c}0.037 * * * \\
(0.002)\end{array}$ & $\begin{array}{c}0.013 * * * \\
(0.001)\end{array}$ & $\begin{array}{c}0.040 * * * \\
(0.001)\end{array}$ \\
\hline European subsidy programme a) & $\begin{array}{c}0.019 * * * \\
(0.003)\end{array}$ & $\begin{array}{c}0.047 * * * \\
(0.003)\end{array}$ & $\begin{array}{c}0.016^{* * *} \\
(0.003)\end{array}$ & $\begin{array}{c}0.050 * * * \\
(0.002)\end{array}$ \\
\hline
\end{tabular}

Notes: ${ }^{\text {a) }}$ The prediction of the probability of participating in each programme is obtained from Table 4 . Bootstrapped standard errors between parentheses. Coefficients significant at $1 \% * * *, 5 \% * *, 10 \% *$. All regressions include the same explanatory variables as estimations in Table 4.

As we have explained before, to face this subject we also apply a matching estimator for the cases depicted in Table 1. To obtain the propensity scores that allow us to build the counterfactual, for each treatment a probit model is estimated considering the same explanatory variables of the multivariate probit presented in Table 4 . The detailed explanations of our matching procedure and the tests that we use to evaluate the implementation of the propensity score matching can be found in Appendix 3.

As for the propensity to engage in R\&D activities, the results in Table 7 show that getting public funding of any type has a positive effect on the decision to undertake R\&D activities as compared to not obtaining public funding at all (cases A to E). In terms of being supported through a unique instrument (cases A, B and C), the largest impact takes place when the firm is awarded a UE grant. Specifically, being supported through European subsidies increases the likelihood of performing internal R\&D activities of non-supported firms by 24.1 percentage points. This impact is more than three times larger than the one of loans. Another interesting result is that the impacts of national or European subsidies are greater on the propensity to engage in total $R \& D$ than on internal $R \& D$, reflecting that these instruments are more effective to stimulate the performance of external R\&D activities. However, the opposite happens in the case of CDTI loans. They seem to have a higher effect on the decision to undertake internal $R \& D$ expenditures.

It is worth noting that, regarding the propensity to undertake $R \& D$ expenditures, no treatment effect is computed for cases $\mathrm{J}$ and $\mathrm{K}$. In these cases, both the actual status and the counterfactual imply getting a subsidy to finance internal $R \& D$. Therefore, all firms engage in $R \& D$ activities. 
There is also a positive effect of all types of support on internal and total $R \& D$. That is, there is not full crowding-out of private $R \& D$ expenditures. This result is in line with Czarnitzki and Lopes-Bento (2014) regarding public subsidies. In addition, when we compare the effects of single treatments (cases A to $\mathrm{C}$ ) with respect to the non-public funding situation, the magnitudes are higher for public subsidies than for CDTI loans.

The rest of the cases in Table 7 allow us to analyse the differences (if they exist) among the effects of the heterogeneous treatments. In particular, the results for case $J$ suggest that there is no difference between being supported only through a national subsidy or a European grant. This result justifies that we consider getting subsidies as a unique treatment regardless of the national or supranational character of the supporting entity (cases D, H, I and K).

Cases F, G and H compare the impact of subsidies with soft loans. As can be seen, firms that are awarded a national and/or a European subsidy would have invested less if they would have received a CDTI loan instead of the grant.

In addition, those companies that receive both subsidies and loans invest more compared to the counterfactual situation of getting funding only from the CDTI (case I). However, the opposite is not the case: adding soft loans to public subsidies does not imply an increase in firms' gross R\&D investment (case K). These two last results would suggest only a partial rejection of the hypothesis of crowding-out effect between subsidies and CDTI loans.

We have also considered the symmetric cases of the combinations analysed in Table 7, interchanging actual treatments with the counterfactuals. This allows wondering, for example, whether non-supported firms would have benefited if they had received a soft loan, a national subsidy or a UE grant, respectively. Our results confirm the direction of the effects. We find negative (non-significant) treatments when the symmetric cases show positive (nonsignificant) treatments in Table $7 .^{10}$

\footnotetext{
${ }^{10}$ These results are available from the authors upon request.
} 
Table 7: Matching results: Effect of public support on R\&D

\begin{tabular}{|c|c|c|c|c|c|c|}
\hline \multirow[b]{2}{*}{ Case } & \multirow[b]{2}{*}{ Actual status } & \multirow[b]{2}{*}{ Counterfactual } & \multicolumn{4}{|c|}{ Dependent variable: } \\
\hline & & & $\begin{array}{c}\text { Propensity to } \\
\text { engage in internal } \\
\text { R\&D (0/1) }\end{array}$ & $\begin{array}{c}\text { Internal } \\
\text { R\&D intensity } \\
\text { (log.) }\end{array}$ & $\begin{array}{l}\text { Propensity to } \\
\text { engage in total } \\
\text { R\&D (0/1) }\end{array}$ & $\begin{array}{l}\text { Total R\&D } \\
\text { intensity } \\
\text { (log.) }\end{array}$ \\
\hline $\mathrm{A}$ & Only CDTI loan & No public funding & $0.075^{* * *}$ & $0.714 * * *$ & $0.068^{* * *}$ & $0.792 * * *$ \\
\hline $\mathrm{B}$ & Only national subsidy & No public funding & $0.173 * * *$ & $1.946 * * *$ & $0.210 * * *$ & $1.752 * * *$ \\
\hline $\mathrm{C}$ & Only European subsidy & No public funding & $0.241 * * *$ & $2.248 * * *$ & $0.262 * * *$ & $2.107 * * *$ \\
\hline $\mathrm{D}$ & Only subsidies & No public funding & $0.190 * * *$ & $2.094 * * *$ & $0.223 * * *$ & $1.899 * * *$ \\
\hline $\mathrm{E}$ & CDTI loans \& subsidies & No public funding & $0.126 * * *$ & $1.727 * * *$ & $0.147 * * *$ & $1.636^{* * *}$ \\
\hline $\mathrm{F}$ & Only national subsidy & Only CDTI loan & $0.101 * * *$ & $0.963 * * *$ & $0.122 * * *$ & $0.859 * * *$ \\
\hline $\mathrm{G}$ & Only European subsidy & Only CDTI loan & $0.140 * * *$ & $1.200 * *$ & $0.161 * * *$ & $1.054 * *$ \\
\hline $\mathrm{H}$ & Only subsidies & Only CDTI loan & $0.109 * * *$ & $0.961 * * *$ & $0.126 * * *$ & $0.846^{* * *}$ \\
\hline I & CDTI loans \& subsidies & Only CDTI loan & $0.071 * * *$ & $1.331 * * *$ & $0.094 * * *$ & $1.200 * * *$ \\
\hline $\mathrm{J}$ & Only European subsidy & Only national subsidy & - & -0.107 & - & -0.134 \\
\hline $\mathrm{K}$ & CDTI loans \& subsidies & Only subsidies & - & 0.172 & - & 0.189 \\
\hline
\end{tabular}

Notes: Bootstrapped standard errors. $* * *, * * *$ indicate a 1 per cent, 5 per cent, and 10 per cent significance level, respectively. In cases $\mathrm{J}$ and $\mathrm{K}$, all firms engage in R\&D activities. 
Finally, in Table 8 we present the results of our matching procedure for two sub-samples: SMEs (with a number of employees between 10 and 199) ${ }^{11}$ and large firms (200 or more employees). In both groups of companies, balancing tests after matching confirm that our matching specification generates well balanced samples (see Appendix 3).

One of the restrictions in our data that could be hindering the estimation of our equation [1] is the absence of control variables reflecting the capital structure of Spanish companies. In this line, the different role of firm size as explanatory variable for the participation in public programmes can also be reflecting a different degree of financial constraints faced by SMEs and large firms. At this respect, the role of public support systems tends to be more relevant for SMEs for which liquidity constraints should be stronger (Zúñiga et al., 2014). Ali-Yrkkö (2005) specifically finds a positive effect of public funding on the R\&D of small firms, which would be more likely to face financial constraints. Using firm-level data from two waves of the Spanish CIS, Busom et al. (2014) also conclude that for SMEs, internal and external financing constraints are positively associated with the likelihood of receiving direct funding. ${ }^{12}$ However, in the case of large firms only the difficulties in external access to funds are positively related to the awarding of direct support.

The results in Table 8 confirm the existence of heterogeneous impacts of public support between these two groups of companies. For SMEs, estimated treatment effects show similar patterns than in the whole sample: all public funding programmes display a relevant effect on the decision to undertake $R \& D$ activities and strongly stimulate internal and total R\&D intensity. The five statuses of public support considered in cases A to E have a positive and significant effect compared with the counterfactual of not obtaining public funding at all. Again, there is not a significant treatment in case J, where we analyse whether firms supported through a national subsidy have a different intensity respect to firms granted with a European subsidy.

\footnotetext{
${ }^{11}$ This is a usual criterion in Spanish statistics because Spanish firm size is smaller than the European average (European Commission, 2003). In particular, in the Spanish Innovation Survey, the population of companies is stratified considering the following brackets, based on the number of employees: 10 to 49,50 to 199, 200 and over. The strata made up of companies with 200 or more employees are analysed exhaustively.

${ }^{12}$ In their analysis, they cannot distinguish between grants and loans. Both are considered as a unique instrument that is compared with R\&D tax incentives.
} 
Table 8: Matching results: Effect of public support on R\&D. Large firms vs SMEs

\begin{tabular}{|c|c|c|c|c|c|c|c|}
\hline & \multirow[b]{2}{*}{ Case } & \multirow[b]{2}{*}{ Actual status } & \multirow[b]{2}{*}{ Counterfactual } & \multicolumn{4}{|c|}{ Dependent variable: } \\
\hline & & & & $\begin{array}{c}\text { Propensity to } \\
\text { engage in internal } \\
\text { R\&D (0/1) }\end{array}$ & $\begin{array}{c}\text { Internal } \\
\text { R\&D intensity } \\
\text { (log.) }\end{array}$ & $\begin{array}{c}\text { Propensity to } \\
\text { engage in total } \\
\text { R\&D (0/1) }\end{array}$ & $\begin{array}{c}\text { Total R\&D } \\
\text { intensity } \\
\text { (log.) }\end{array}$ \\
\hline \multirow{11}{*}{ Large firms } & $\mathrm{A}$ & Only CDTI loan & No public funding & 0.049 & $0.503 * * *$ & $0.071^{* * *}$ & $0.606^{* * *}$ \\
\hline & $\mathrm{B}$ & Only national subsidy & No public funding & $0.096 * * *$ & $0.629 * * *$ & $0.079 * * *$ & $0.545 * * *$ \\
\hline & $\mathrm{C}$ & Only European subsidy & No public funding & $0.122 *$ & 0.712 & $0.098^{*}$ & 0.548 \\
\hline & $\mathrm{D}$ & Only subsidies & No public funding & $0.109 * * *$ & $0.962 * * *$ & $0.091 * * *$ & $0.840 * * *$ \\
\hline & $\mathrm{E}$ & CDTI loans \& subsidies & No public funding & $0.150 * * *$ & $1.320 * * *$ & $0.135 * * *$ & $1.428 * * *$ \\
\hline & $\mathrm{F}$ & Only national subsidy & Only CDTI loan & 0.065 & 0.553 & 0.032 & 0.445 \\
\hline & G & Only European subsidy & Only CDTI loan & 0.167 & 1.002 & 0.125 & 0.783 \\
\hline & $\mathrm{H}$ & Only subsidies & Only CDTI loan & $0.093 * *$ & $0.758 * *$ & $0.056^{*}$ & $0.579 *$ \\
\hline & I & CDTI loans \& subsidies & Only CDTI loan & 0.052 & 0.493 & 0.026 & $0.442 *$ \\
\hline & $\mathrm{J}$ & Only European subsidy & Only national subsidy & - & 0.137 & - & 0.040 \\
\hline & $\mathrm{K}$ & CDTI loans \& subsidies & Only subsidies & - & 0.065 & - & 0.100 \\
\hline \multirow{11}{*}{ SMEs } & $\mathrm{A}$ & Only CDTI loan & No public funding & $0.107 * * *$ & $1.237 * * *$ & $0.107 * * *$ & $1.270 * * *$ \\
\hline & $\mathrm{B}$ & Only national subsidy & No public funding & $0.263 * * *$ & $2.528 * * *$ & $0.239 * * *$ & $2.448 * * *$ \\
\hline & $\mathrm{C}$ & Only European subsidy & No public funding & $0.299 * * *$ & $2.842 * * *$ & $0.253 * * *$ & $2.524 * * *$ \\
\hline & $\mathrm{D}$ & Only subsidies & No public funding & $0.267 * * *$ & $2.580 * * *$ & $0.238 * * *$ & $2.427 * * *$ \\
\hline & $\mathrm{E}$ & CDTI loans \& subsidies & No public funding & $0.178 * * *$ & $2.247 * * *$ & $0.147 * * *$ & $2.082 * * *$ \\
\hline & $\mathrm{F}$ & Only national subsidy & Only CDTI loan & $0.146 * * *$ & $1.166^{* * *}$ & $0.114 * * *$ & $0.971 * * *$ \\
\hline & $\mathrm{G}$ & Only European subsidy & Only CDTI loan & $0.164 * * *$ & $1.397 * * *$ & $0.134 * * *$ & $1.085^{*}$ \\
\hline & $\mathrm{H}$ & Only subsidies & Only CDTI loan & $0.143 * * *$ & $1.272 * * *$ & $0.110 * * *$ & $1.088 * * *$ \\
\hline & I & CDTI loans \& subsidies & Only CDTI loan & $0.071 * * *$ & $1.232 * * *$ & $0.078 * *$ & $1.115^{* * *}$ \\
\hline & $\mathrm{J}$ & Only European subsidy & Only national subsidy & - & 0.132 & - & 0.030 \\
\hline & $\mathrm{K}$ & CDTI loans \& subsidies & Only subsidies & - & $0.415^{* * *}$ & - & $0.443 * * *$ \\
\hline
\end{tabular}

Notes: Bootstrapped standard errors. ${ }^{* *}, * *, *$ indicate a 1 per cent, 5 per cent, and 10 per cent significance level, respectively. In cases $\mathrm{J}$ and $\mathrm{K}$, all firms engage in R\&D activities. 
In addition, the hypothesis of crowding-out effect between subsides and loans is rejected both in cases $\mathrm{H}$ and $\mathrm{K}$ : Firms who receive subsidies and loans invest more in R\&D activities compared to the counterfactual situation of getting funding only through a loan or only through a subsidies. That is, for SMEs, there is a complementarity among the different schemes of public funding: adding together multiple aids results in higher resources for R\&D\&I activities.

However, the effects of public support are much smaller in the case of large firms. In addition, recipients of a national or a European subsidy would have invested similarly if they had benefited from a CDTI loan (cases F and G). Accordingly, we cannot find clear evidence of complementarity among subsidies and CDTI loans (cases I and K).

These findings suggest that, regardless of the firm size, subsidy programmes are more effective than low-interest loans to foster R\&D activities of Spanish companies. For SMEs, which are more subject to internal financial constraints, multiple programme participation has a higher effect than a single scheme use. However, in case of large firms we cannot reject the hypothesis of crowding-out effect between subsidies and CDTI loans.

\section{CONCLUSIONS}

Empirical evidence on the impact of public aid on private R\&D has substantially increased during the last decades, with a multiplicity of methodologies used to control for potential endogeneity of public support. However, most papers examine only the impact of one support programme and this fact prevents the comparison of the effects among different policy instruments.

The objective of our study is to contribute to this debate by examining the effect of participating within three types of instruments used by public administrations to support Spanish firms: the programme of low-interest loans provided by the CDTI, the main national agency which finances firms' R\&D projects; the national scheme of R\&D subsidies; and the European system of R\&D grants. This will allow us to analyse the relative relevance of two features of public programmes: the national or supranational character of the financing agency and the magnitude of reimbursement implied in the design of public support. To our knowledge, no previous empirical research exists comparing the effects of public subsidies and loans on private $R \& D$. 
To face the typical selectivity and endogeneity problems that are present in this kind of analysis, we follow two alternative methodologies. Initially, we use a Heckman's treatment effect model, which consists of two stages. In the first stage, we estimate a multivariate probit model to study the determinants of participation in each of the three public programmes. Afterwards, in a second stage, we analyse how this participation affects the $R \& D$ intensity of the firms. We complement this treatment analysis employing an econometric matching procedure. This procedure allows us to test whether there is substitutability or complementarity among the different public funding policies.

The results obtained for a sample of 4,407 Spanish firms during the period 2002-2005 can be summarised as follows:

Firstly, participation in national subsidy programmes and participation in European subsidy programmes are positively linked to each other. The same happens with CDTI soft loans and national subsidies schemes, indicating the presence of common unobserved factors that affect the probability of participating in both programmes. In addition, we find that the participants within the three systems of public aid have different features, suggesting that the programmes do not completely overlap in terms of their recipients.

Secondly, regardless of the methodology employed for the analysis, being awarded public aid clearly increases the probability of conducting R\&D activities. In terms of being supported through a unique instrument, the greatest effect corresponds to the case of European grants, where the impact is more than three times larger than the one of loans. In order to stimulate firms to engage in R\&D activities, this suggests that it may be better to support them through subsidies than through low-interest loans. As for the intensive margin, the hypothesis of full crowding-out of private $R \& D$ is rejected for all types of support.

Thirdly, we find different impacts when we distinguish between SMEs and large firms. For the first, which are more subject to financial constraints, estimated average treatment effects are in general higher. In addition, both in terms of extensive and intensive margins, multiple programme participation has a higher effect than a single scheme use. However, we cannot rule out the existence of crowding-out effect between subsidies and CDTI loans in the case of large firms. Therefore, the effectiveness of innovation policy differs depending on firm size. Any type of direct support has a higher impact on the propensity to perform R\&D activities of SMEs. In addition, for large firms, that are supposed to be less financially restricted, public 
agencies should be conscious that multiple programme participation could not cause an increase of recipients' R\&D investment as compared to a situation of single programme participation.

An aspect that remains to be studied is whether our conclusions remain with regard to firms' technological outputs as process and product innovations, or patents. For this task, it would be necessary to have information on the amount of funding awarded to each firm through each public programme. This information would also allow for testing not only full but partial crowding out of public funding.

Furthermore, it could be crucial to study the role of repeated support. Previous research stresses that firms with past experience in a support programme have a higher probability of participating again because they learn from previous participation which reduces their costs for re-applying (Hernán et al., 2003; Barajas and Huergo, 2010). At the same time, public support can have a certifying effect on innovative companies, helping these firms to obtain private external financing in future periods and, therefore, making public aid less necessary. Note also that, since the matching procedure models selection only on observed characteristics, the availability of information about previous participation in public support programmes would ensure the reliability of the results.

Finally, our analysis is limited to the effect of public direct support on business R\&D for the specific case of Spanish firms. It would be also relevant to extend the analysis to other countries to check the generalization of our results.

\section{REFERENCES}

Aerts, K., D. Czarnitzki and A. Fier (2006), "Evaluación econométrica de la política pública de I+D: estado del arte," in Heijs and Buesa (eds.): La cooperación en innovación en España, el papel del estado. Instituto de Estudios Fiscales, España.

Ali-Yrkkö, J. (2005), "Impact of public R\&D financing on private R\&D. Does financial constraint matter?" Working Paper No. 30. ENEPRI, Brussels.

Aristei, D., A. Sterlacchini and F. Venturini (2015), "The effects of public supports on business R\&D: firm-level evidence across EU countries", MPRA Paper No. 64611, University Library of Munich, Germany. 
Arvanitis, S. and H. Hollenstein (1994), "Demand and supply factors in explaining the innovative activity of Swiss manufacturing firms," Economics of Innovation and New Technology, 3, 15-30.

Audretsch, D. (1995), Innovation and Industry Evolution, MIT Press: Cambridge, MA.

Barajas, A. and E. Huergo (2010), "International R\&D cooperation within the EU Framework Programme: empirical evidence for Spanish firms," Economics of Innovation and New Technology, 19(1-2), 87-111.

Barajas, A., E. Huergo and L. Moreno (2016), "SME performance and public support for international RJVs,” Journal of Small Business Management, 54(4), 1206-1228.

Bayona-Sáez, C. and T. García-Marco (2010), "Assessing the effectiveness of the Eureka program," Research Policy, 39, 1375-1386.

Becker, B. (2015), "Public R\&D policies and private R\&D investment: A survey of the empirical evidence," Journal of Economic Surveys, 29(5), 917-942.

Beneito, P. (2003), "Choosing among alternative technological strategies: An empirical analysis of formal sources of innovation," Research Policy, 32, 693-713.

Benfratello, L. and A. Sembenelli (2002), "Research joint ventures and firm-level performance," Research Policy, 31, 493-507.

Blanes, J. V. and I. Busom (2004), "Who participates in R\&D subsidy programs? The case of Spanish manufacturing firms," Research Policy, 33(10), 1459-1476.

Busom, I. (2000), "An empirical evaluation of the effects of R\&D subsidies," Economics of Innovation and New Technology, 9(2), 111-148.

Busom, I., M. B. Corchuelo and E. Martínez-Ros (2014), "Tax incentives... or subsidies for business R\&D?” Small Business Economics, 43(3), 571-96.

Busom, I., M. B. Corchuelo and E. Martínez-Ros (2016), "Participation inertia in R\&D tax incentive and subsidy programs," Small Business Economics, forthcoming. DOI: $10.1007 / \mathrm{s} 11187-016-9770-5$.

Busom, I. and A. Fernández-Ribas (2007), "Do R\&D Programs of different government levels overlap in the European Union?" Science, Technology and Innovation Policy, Atlanta Conference, 1-5.

Cappellari, L. and S.P. Jenkins (2003), "Multivariate probit regression using simulated maximum likelihood," The Stata Journal, 3(3), 278-294.

Cassiman B. and R. Veugelers (2002), "R\&D Cooperation and Spillovers: Some Empirical Evidence from Belgium," American Economic Review, 92(4), 1169-1184.

Cerulli, G. and B. Potì (2012), "Evaluating the robustness of the effect of public subsidies on a firm's R\&D: An application to Italy", Journal of Applied Economics, 15(2), 287320. 
Clausen, T. H. (2008), "Do subsidies have positive impacts on R\&D and innovations activities at the firm level?" TIK Working papers on Innovation Studies No. 20070615. Oslo.

Czarnitzki, D. and G. Licht (2006), "Additionality of Public R\&D grants in a transition economy: the case of Eastern Germany," The Economics of Transition, 14(1), 101-131.

Czarnitzki D., B. Ebersberger and A. Fier (2007), "The relationship between R\&D Collaboration, subsidies and R\&D performance: Empirical evidence from Finland and Germany," Journal of Applied Econometrics, 22(7), 1347-1366.

Czarnitzki, D. and C. Lopes-Bento (2014), "Innovation subsidies: Does the funding source matter for innovation intensity and performance? Empirical evidence from Germany," Industry and Innovation, 21(5), 380-409.

David, P.A., Hall B. H. and A. A. Toole (2000), "Is public R\&D a complement or substitute for private R\&D? A review of the econometric evidence," Research Policy, 29, 497529.

Duguet, E. (2004), “Are R\&D subsidies a substitute or a complement to privately funded R\&D? Evidence from France using propensity score methods for non-experimental data," Revue d'Economie Politique, 114(2), 263-292.

European Commission (2003), SMEs in Europe 2003. The European Observatory for SMEs. Luxembourg: Office for Official Publications of the European Communities.

European Commission (2009), Analysing and Evaluating the Impact on Innovation of Publicly Funded Research Programmes: Lot 2 - Benchmarking Strategies and Methodologies of National, European and International R\&D Programmes to Assess and Increase their Impact on Innovation, Final Report, European Commission, DG Enterprise.

García, A. and P. Mohnen (2010), "Impact of government support on R\&D and innovation," UNU-MERIT Working Paper Series 2010-034, United Nations University, Maastricht Economic and Social Research and Training Centre on Innovation and Technology.

Gerfin, M. and M. Lechner (2002), "A microeconometric evaluation of active labour market policy in Switzerland", Economic Journal, 112, 845-893.

González, X., Jaumandreu, J. and C. Pazó (2005), "Barriers to innovation and subsidy effectiveness," The Rand Journal of Economics, 36(4), 930-949.

González, X. and C. Pazó (2008), "Do public subsidies stimulate private R\&D spending?" Research Policy, 37(3), 371-389.

Griffith, R., E. Huergo, J. Mairesse and B. Peters (2006), "Innovation and productivity across four European countries," Oxford Review of Economic Policy, 22(4), 483-498.

Guo, S. and M. W. Fraser (2010), Propensity Score Analysis: Statistical Methods and Applications, SAGE publications, Inc.

Hall, B. H. (2002), "The financing of research and development," Oxford Review of Economic Policy, 18(1), 35-51. 
Hall, B. and J. Lerner (2010), "The Financing of R\&D and Innovation," Handbook of the Economics of Innovation, Vol. 1, 609-639.

Hall, B., Lotti, F. and J. Mairesse (2009), "Innovation and productivity in SMEs. Empirical evidence for Italy," Small Business Economics, 33, 13-33.

Heckman, J. J. (1979), "Sample selection bias as a specification error," Econometrica, 47, $153-162$.

Heijs, J. (2005), "Identification of firms supported by technology policies: the case of Spanish low interest credits," Science and Public Policy, 32(3), 219-230.

Heijs, J. (2011), Mini Country Report/SPAIN, Thematic Report 2011 under Specific Contract for the Integration of INNO Policy Trend Chart with ERAWATCH (2011-2012), http://ec.europa.eu/enterprise/policies/innovation/files/countryreports/spain_en.pdf.

Hernán, R., Marín, P. and G. Siotis (2003), “An empirical evaluation of the determinants of research joint venture formation,” Journal of Industrial Economics, 51(1), 75-89.

Hottenrott, H. and C. Lopes-Bento (2014), "(International) R\&D collaboration and SMEs: The effectiveness of targeted public R\&D support schemes," Research Policy, 41, 1055-1066.

Huergo, E. and J. Jaumandreu (2004), "Firms' age, process innovation and productivity growth," International Journal of Industrial Organization, 22, 541- 559.

Huergo, E. and L. Moreno (2011), "Does history matter for the relationship between R\&D, innovation and productivity?" Industrial and Corporate Change, 20(5), 1335-1368.

Huergo, E. and M. Trenado (2010), "The Application for and the Awarding of Low-Interest Credits to Finance R\&D Projects," Review of Industrial Organization, 37(3), 237-259.

Huergo, E., Trenado, M. and A. Ubierna (2016), "The impact of public support on firm propensity to engage in R\&D: Spanish experience," Technological Forecasting and Social Change, 116, 206-219.

Kaiser, U. and J. M. Kuhn (2012), "Long-run effects of public-private joint ventures: The case of the Danish Innovation Consortia support scheme," Research Policy, 41, 913-927.

Klepper, S. (1996), "Entry, exit, and innovation over the product life-cycle," American Economic Review, 86, 562-583.

Lach, S. (2002), "Do R\&D subsidies stimulate or displace private R\&D? Evidence from Israel," Journal of Industrial Economics 50(4), 369-390.

Lerner, J. (2002), "When bureaucrats meet entrepreneurs: the design of effective 'public venture capital' programmes," The Economic Journal, 112(477), F73-F84.

Leuven, E. and B. Sianesi (2003), "PSMATCH": "Stata module to perform full Mahalanobis and propensity score matching, common support graphing, and covariate imbalance testing," Statistical Software Components S432001, Boston College Department of economics. 
Liu, R. and C. Rammer (2016), "The contribution of different public innovation funding programs to SMEs' export performance”, ZEW Discussion Paper No. 16-078. ZEW (Centre for European Economic Research), Mannheim, Germany.

OECD (2006), Government R\&D funding and company behaviour. Measuring behavioural additionality. OECD report.

OECD (2010), Measuring Innovation: A New Perspective. OECD Publishing.

OECD (2012), OECD Science, Technology and Industry Outlook 2012, OECD Publishing.

OECD (2015), Compendium of R\&D tax incentive schemes: OECD countries and selected economies, 2015, www.oecd.org/sti/rd-tax-stats.htm.

Ortega-Argilés, R., R. Moreno and J. Suriñach-Caralt (2005), “Ownership structure and innovation: Is there a real link?” The Annals of Regional Science, 39(4), 637-662.

Piva, M. and M. Vivarelli (2009), "The role of skills as a major driver of corporate R\&D," International Journal of Manpower, 30(8), 835-852.

Takalo, T., Tanayama, T. and O. Toivanen (2013), "Estimating the benefits of targeted R\&D subsidies," The Review of Economics and Statistics, 95(1), 255-272.

Wallsten, S.J. (2000), "The effects of government-industry R\&D programs on private R\&D: the case of the Small Business Innovation Research Program," The Rand Journal of Economics, 31(1), 82-100.

Zúñiga-Vicente, J.A., Alonso-Borrego, C., Forcadell, F. J. and J. I. Galán (2014), “Assessing the effect of public subsidies on firm R\&D investment: a survey," Journal of Economics Surveys, 28(1), 36-67. 


\section{Appendix 1: Definitions of variables}

All variables but CDTI loan were provided by the Spanish Institute of Statistics from the Technological Innovation Survey. The information about loans comes from the CDTI database. See the unit of measurement of each variable in Table A.2 of Appendix 2.

Belonging to a group: dummy variable which takes the value 1 if the firm belongs to a group.

CDTI loan: dummy variable which takes the value 1 if the firm has been awarded a CDTI soft loan during the year.

European subsidy: dummy variable which takes the value 1 if the firm has been awarded a European subsidy during the year.

Exporter: Dummy variable which takes the value 1 if the company exported during the period.

Foreign capital: Dummy variable which takes the value 1 when the firm is partly owned by a foreign firm (more than $50 \%$ of foreign capital during the period).

High and medium-tech manufacturing: Dummy variable which takes the value 1 if the company belongs to any high or medium-tech manufacturing sectors (NACE2 codes 24, 29, $30,31,32,33,34,35)$.

High and medium-tech services: Dummy variable which takes the value 1 if the company belongs to high-tech services (NACE2 codes $64,72,73,92$ )

Internal R\&D intensity: Ratio of internal expenditures on R\&D over total employment.

National subsidy: dummy variable which takes the value 1 if the firm has been awarded a national subsidy during the year.

Public firm: Dummy variable which takes the value 1 when the firm is partly publicly owned (more than $50 \%$ of public capital during the period).

R\&D performer: Dummy variable which takes the value 1 if the firm has positive expenditures on $R \& D$ during the year.

Relative labour productivity: Ratio of firm labour productivity (sales over employment) over the industry average at NACE 2-digit level.

Size: number of employees during the current year.

Start-up: dummy variable which takes the value 1 if the firm was created during the last three years.

Technological cooperation: Dummy variable which takes the value 1 if the company established technological cooperation agreements during the last three years with other partners.

Total R\&D intensity: Ratio of total expenditures on R\&D (including technology imports) over total employment. 
Appendix 2

Table A.1: Matching possibilities

\begin{tabular}{|c|c|c|c|c|c|c|c|c|c|}
\hline \multirow[b]{2}{*}{ Counterfactual } & \multirow[b]{2}{*}{$\begin{array}{c}\text { N. of } \\
\text { Obser. }\end{array}$} & \multicolumn{8}{|c|}{$\begin{array}{c}\text { Dependent variable: } \\
\text { Actual status }\end{array}$} \\
\hline & & $\begin{array}{l}\text { No public } \\
\text { funding }\end{array}$ & $\begin{array}{l}\text { Only } \\
\text { CDTI } \\
\text { loan }\end{array}$ & $\begin{array}{c}\text { Only } \\
\text { national } \\
\text { subsidy }\end{array}$ & $\begin{array}{c}\text { Only } \\
\text { European } \\
\text { subsidy }\end{array}$ & $\begin{array}{c}\text { CDTI loan \& } \\
\text { national } \\
\text { subsidy }\end{array}$ & $\begin{array}{l}\text { CDTI loan \& } \\
\text { European } \\
\text { subsidy }\end{array}$ & $\begin{array}{c}\text { National \& } \\
\text { European } \\
\text { subsidies }\end{array}$ & $\begin{array}{l}\text { All types } \\
\text { of public } \\
\text { funding }\end{array}$ \\
\hline No public funding & 9.662 & & Case 1 & Case 2 & Case 3 & Case 4 & Case 5 & Case 6 & Case 7 \\
\hline Only CDTI loan & 1.108 & Case 29 & & Case 8 & Case 9 & Case 10 & Case 11 & Case 12 & Case 13 \\
\hline Only national subsidy & 1.451 & Case 30 & Case 31 & & Case 14 & Case 15 & Case 16 & Case 17 & Case 18 \\
\hline Only European subsidy & 322 & Case 32 & Case 33 & Case 34 & & Case 19 & Case 20 & Case 21 & Case 22 \\
\hline CDTI loan \& national subsidy & 587 & Case 35 & Case 36 & Case 37 & Case 38 & & Case 23 & Case 24 & Case 25 \\
\hline CDTI loan \& European subsidy & 32 & Case 39 & Case 40 & Case 41 & Case 42 & Case 43 & & Case 26 & Case 27 \\
\hline National \& European subsidies & 324 & Case 44 & Case 45 & Case 46 & Case 47 & Case 48 & Case 49 & & Case 28 \\
\hline All types of public funding & 60 & Case 50 & Case 51 & Case 52 & Case 53 & Case 54 & Case 55 & Case 56 & \\
\hline Total & 13.546 & & & & & & & & \\
\hline
\end{tabular}

Note: Cases in bold could not be estimated due to data limitations. 
Table A.2: Statistics of main variables

\begin{tabular}{|c|c|c|c|c|c|}
\hline & Mean & S.D. & Min & Max & Median \\
\hline \multicolumn{6}{|l|}{ R\&D funding (1/0) } \\
\hline Own funding & 0.563 & 0.496 & 0 & 1 & 1 \\
\hline CDTI loan & 0.132 & 0.238 & 0 & 1 & 0 \\
\hline National subsidy & 0.177 & 0.381 & 0 & 1 & 0 \\
\hline European subsidy & 0.054 & 0.227 & 0 & 1 & 0 \\
\hline \multicolumn{6}{|l|}{ Other firm characteristics $(1 / 0)$} \\
\hline Belonging to a group & 0.399 & 0.490 & 0 & 1 & 0 \\
\hline Exporter & 0.548 & 0.498 & 0 & 1 & 1 \\
\hline Foreign capital & 0.115 & 0.319 & 0 & 1 & 0 \\
\hline High and medium-tech manufacturing & 0.235 & 0.424 & 0 & 1 & 0 \\
\hline High and medium-tech services & 0.096 & 0.295 & 0 & 1 & 0 \\
\hline Internal $\mathrm{R} \& \mathrm{D}$ performer & 0.592 & 0.491 & 0 & 1 & 1 \\
\hline Public firm & 0.020 & 0.139 & 0 & 1 & 0 \\
\hline R\&D performer (internal and external) & 0.625 & 0.484 & 0 & 1 & 1 \\
\hline Start-up & 0.032 & 0.172 & 0 & 1 & 0 \\
\hline Technological cooperation with: & 0.340 & 0.474 & 0 & 1 & 0 \\
\hline - clients & 0.088 & 0.283 & 0 & 1 & 0 \\
\hline - competitors & 0.062 & 0.242 & 0 & 1 & 0 \\
\hline - consultants \& laboratories & 0.081 & 0.273 & 0 & 1 & 0 \\
\hline - PRCs & 0.081 & 0.273 & 0 & 1 & 0 \\
\hline - other firms of the group & 0.078 & 0.269 & 0 & 1 & 0 \\
\hline - providers & 0.126 & 0.332 & 0 & 1 & 0 \\
\hline - technological centres & 0.128 & 0.334 & 0 & 1 & 0 \\
\hline - universities & 0.168 & 0.374 & 0 & 1 & 0 \\
\hline \multicolumn{6}{|l|}{ Other firm characteristics (quantitative): } \\
\hline Export intensity (Export over sales) & 0.171 & 0.263 & 0 & 1 & 0.011 \\
\hline External R\&D Expenditures (K€) & 235.7 & $2,239.1$ & 0 & 54,800 & 0 \\
\hline Internal R\&D Expenditures (K€) & 719.5 & $3,910.4$ & 0 & 72,300 & 53.6 \\
\hline Percentage of R\&D employees (\%) & 43.1 & 42.0 & 0 & 100 & 38.3 \\
\hline R\&D intensity (K€ per employee) & 7.0 & 27.8 & 0 & $1,268.4$ & 0.8 \\
\hline Relative labour productivity & 1.0 & 2.9 & 0 & 178.0 & 0.7 \\
\hline Size (Number of employees) & 358.2 & $1,096.8$ & 1 & 13,023 & 69 \\
\hline Total R\&D intensity (K€ per employee) & 8.7 & 34.9 & 0 & $1,441.2$ & 1.1 \\
\hline Number of observations (firms) & \multicolumn{5}{|c|}{$13,546(4,407)$} \\
\hline
\end{tabular}


Table A.3: Industries in the estimation sample

\begin{tabular}{|c|c|c|c|c|c|c|c|c|c|c|}
\hline \multirow[b]{2}{*}{ Industries } & \multirow[b]{2}{*}{ NACE2 codes } & \multicolumn{9}{|c|}{ Number of observations } \\
\hline & & Total & $\begin{array}{l}\text { No public } \\
\text { funding }\end{array}$ & $\begin{array}{l}\text { Only } \\
\text { CDTI } \\
\text { loan }\end{array}$ & $\begin{array}{c}\text { Only } \\
\text { national } \\
\text { subsidy }\end{array}$ & $\begin{array}{c}\text { Only } \\
\text { European } \\
\text { subsidy }\end{array}$ & $\begin{array}{c}\text { CDTI loan } \\
\text { \& national } \\
\text { subsidy } \\
\end{array}$ & $\begin{array}{c}\text { CDTI loan \& } \\
\text { European } \\
\text { subsidy }\end{array}$ & $\begin{array}{c}\text { National \& } \\
\text { European } \\
\text { subsidies }\end{array}$ & $\begin{array}{l}\text { All types } \\
\text { of public } \\
\text { funding }\end{array}$ \\
\hline 1. Agriculture & $1-5$ & 20 & 12 & 3 & 3 & 1 & 0 & 1 & 0 & 0 \\
\hline 2. Extractive industry and Energy & $10-14,23,40-41$ & 130 & 90 & 5 & 10 & 11 & 1 & 0 & 11 & 2 \\
\hline 3. Low-tech manufacturing & $\begin{array}{l}15-22,25-28,36 \\
37\end{array}$ & 2789 & 2121 & 241 & 234 & 27 & 126 & 9 & 23 & 8 \\
\hline 4. High \& medium-tech manufacturing & $24,29-35$ & 2144 & 1280 & 291 & 286 & 34 & 174 & 5 & 58 & 16 \\
\hline 5. Construction & 45 & 37 & 22 & 6 & 3 & 2 & 0 & 0 & 2 & 2 \\
\hline $\begin{array}{l}\text { 6. Retail and whole sale trade, sale, } \\
\text { maintenance and repair of vehicles }\end{array}$ & $50-52$ & 773 & 712 & 17 & 35 & 3 & 5 & 0 & 1 & 0 \\
\hline 7. Transport service & $60-63$ & 228 & 213 & 3 & 6 & 6 & 0 & 0 & 0 & 0 \\
\hline $\begin{array}{l}\text { 8. Financial intermediation and real } \\
\text { estate activities }\end{array}$ & $65-67,70$ & 214 & 204 & 1 & 4 & 4 & 0 & 1 & 0 & 0 \\
\hline 9. Other low-tech services & $\begin{array}{l}55,71,74-75,80 \\
85,90-91,93\end{array}$ & 1556 & 1260 & 29 & 160 & 30 & 22 & 4 & 42 & 9 \\
\hline 10. High \& medium-tech services & $64,72-73,92$ & 825 & 474 & 40 & 157 & 29 & 34 & 3 & 84 & 4 \\
\hline Total & & 8,716 & 6,388 & 636 & 898 & 147 & 362 & 23 & 221 & 41 \\
\hline
\end{tabular}


Table A.4: Transition rates across participation status

\begin{tabular}{|c|c|c|c|c|c|c|c|c|c|c|}
\hline \multirow[b]{2}{*}{ Status in $t-1$} & \multirow[b]{2}{*}{$\begin{array}{c}\text { Number of } \\
\text { observations }\end{array}$} & \multicolumn{8}{|c|}{ Status in $\mathrm{t}$} & \\
\hline & & $\begin{array}{c}\text { No } \\
\text { public } \\
\text { funding }\end{array}$ & $\begin{array}{l}\text { Only } \\
\text { CDTI } \\
\text { loan }\end{array}$ & $\begin{array}{c}\text { Only } \\
\text { national } \\
\text { subsidy }\end{array}$ & $\begin{array}{c}\text { Only } \\
\text { European } \\
\text { subsidy }\end{array}$ & $\begin{array}{c}\text { CDTI } \\
\text { loan \& } \\
\text { national } \\
\text { subsidy }\end{array}$ & $\begin{array}{c}\text { CDTI } \\
\text { loan \& } \\
\text { European } \\
\text { subsidy } \\
\end{array}$ & $\begin{array}{c}\text { National } \\
\& \\
\text { European } \\
\text { subsidies }\end{array}$ & $\begin{array}{c}\text { All types } \\
\text { of public } \\
\text { funding }\end{array}$ & \\
\hline No public funding & 6,124 & 84.7 & 6.7 & 5.0 & 0.7 & 2.1 & 0.2 & 0.6 & 0.1 & 100 \\
\hline Only CDTI loan & 677 & 65.7 & 12.4 & 15.1 & 1.0 & 4.7 & 0.0 & 1.0 & 0.0 & 100 \\
\hline Only national subsidy & 1,009 & 45.3 & 9.2 & 28.1 & 1.4 & 12.7 & 0.3 & 2.9 & 0.2 & 100 \\
\hline Only European subsidy & 233 & 54.1 & 3.4 & 7.3 & 21.0 & 2.2 & 2.6 & 8.2 & 1.3 & 100 \\
\hline CDTI loan \& national subsidy & 403 & 34.2 & 8.7 & 38.0 & 0.7 & 14.1 & 0.5 & 2.2 & 1.5 & 100 \\
\hline CDTI loan \& European subsidy & 21 & 33.3 & 4.8 & 4.8 & 14.3 & 9.5 & 0.0 & 19.1 & 14.3 & 100 \\
\hline National \& European subsidies & 218 & 13.8 & 3.2 & 15.6 & 10.6 & 4.6 & 0.9 & 47.7 & 3.7 & 100 \\
\hline All types of public funding & 48 & 10.4 & 4.2 & 14.6 & 8.3 & 2.1 & 2.1 & 31.3 & 27.1 & 100 \\
\hline Total & 8,733 & 73.2 & 7.3 & 10.4 & 1.7 & 4.2 & 0.3 & 2.5 & 0.5 & 100 \\
\hline
\end{tabular}


Table A.5: Pairwise correlation matrix

\begin{tabular}{|c|c|c|c|c|c|c|c|c|c|c|c|c|c|c|c|}
\hline & & [1] & [2] & [3] & [4] & {$[5]$} & [6] & [7] & [8] & [9] & [10] & [11] & [12] & [13] & [14] \\
\hline$[1]$ & Patent application & 1 & & & & & & & & & & & & & \\
\hline$[2]$ & Percentage of R\&D employees & $0.308^{*}$ & 1 & & & & & & & & & & & & \\
\hline$[3]$ & TC with clients & $0.118^{*}$ & $0.153 *$ & 1 & & & & & & & & & & & \\
\hline$[4]$ & TC with competitors & $0.136^{*}$ & $0.176^{*}$ & $0.305^{*}$ & 1 & & & & & & & & & & \\
\hline$[5]$ & $\mathrm{TC}$ with other firms from the group & $0.136^{*}$ & $0.197 *$ & $0.276^{*}$ & $0.339^{*}$ & 1 & & & & & & & & & \\
\hline$[6]$ & TC with providers & $0.082 *$ & $0.162 *$ & $0.200 *$ & $0.238^{*}$ & $0.314^{*}$ & 1 & & & & & & & & \\
\hline$[8]$ & TC with universities, PRCs and technological centres & $0.219^{*}$ & $0.330 *$ & $0.258 *$ & $0.350^{*}$ & $0.336^{*}$ & $0.276^{*}$ & $0.331 *$ & 1 & & & & & & \\
\hline [9] & Belonging to a group & $0.058 *$ & $0.049 *$ & $0.304 *$ & $0.090 *$ & $0.049 *$ & $0.043 *$ & $0.078 *$ & $0.054 *$ & 1 & & & & & \\
\hline$[10]$ & Exporter & $0.190 *$ & $0.269 *$ & $0.082 *$ & $0.089 *$ & $0.088 *$ & $0.055^{*}$ & $0.060 *$ & $0.165^{*}$ & $0.092 *$ & 1 & & & & \\
\hline [11] & Foreign capital & $0.029^{*}$ & 0.024 & $0.120 *$ & 0.019 & $0.032 *$ & 0.020 & 0.007 & 0.001 & $0.375^{*}$ & $0.124^{*}$ & 1 & & & \\
\hline [12] & Public firm & $-0.039 *$ & $-0.043^{*}$ & -0.009 & 0.019 & -0.019 & 0.013 & -0.012 & -0.005 & $-0.033^{*}$ & $-0.117^{*}$ & $-0.055^{*}$ & 1 & & \\
\hline [13] & Size & 0.018 & $-0.048 *$ & $0.180^{*}$ & $0.105^{*}$ & 0.021 & $0.043 *$ & $0.072 *$ & -0.004 & $0.446^{*}$ & $0.059 *$ & $0.270 *$ & $0.122 *$ & 1 & \\
\hline
\end{tabular}

Notes: TC stands for technological cooperation. * correlation coefficient significant at the $5 \%$ level. 


\section{Appendix 3: Description of the matching procedure}

In this appendix, we describe the Propensity Score Matching (PSM) technique that we use to construct a sample of firms with characteristics similar to each treated group in Tables 7 and 8. To compute the propensity score for our matching routine, for each treatment we use the same specification of the multivariate probit of equation [1]. We choose the caliper matching algorithm with replacing, in which treated companies are matched with the non-treated ones (control group) that are closest in terms of the propensity score subject to the constraint that there has to be at most a maximum distance of 0.05 between the treated and non-treated firm. The procedure is performed in Stata 13, using the psmatch2 routine implemented by Leuven and Sianesi (2003).

To tests the matching quality we check whether the distribution of covariates is balanced in the treated and control groups (Tables A.6 and A.7). Specifically, we analyse if all variables have the same mean in the two groups and we also report whether, after matching, the covariates no longer explain the probability of participation well. In all cases presented in Tables 7 and 8, our matching procedure has been able to balance the treated and non-treated groups, creating a homogenous group with common characteristics before participation in each public funding programme.

Specifically, Tables A.6 and A.7 show the balancing tests after matching, respectively for the entire sample and distinguishing between SMEs and large firms. As you can see in the last column of both tables, in none of the cases the LR-Chi2 statistic exceeds the critical value at the 5 per cent significance level. In addition, the Pseudo-R2 after matching is close to zero in most cases. Therefore, after matching the covariates do not seem to have any explanatory power to predict the participation into the funding programme. In this sense, it seems that our matching specification generates well balanced samples. 
Table A.6: Balancing tests after matching. All firms

\begin{tabular}{cllccc}
\hline \hline Case & Actual status & Counterfactual & Ps R2 & LR Chi2(19) & p $>$ Chi2 \\
\hline A & Only CDTI loan & No public funding & 0.007 & 12.42 & 0.867 \\
B & Only national subsidy & No public funding & 0.009 & 21.32 & 0.319 \\
C & Only European subsidy & No public funding & 0.041 & 16.54 & 0.621 \\
D & Only subsidies & No public funding & 0.005 & 17.76 & 0.539 \\
E & CDTI loans \& subsidies & No public funding & 0.015 & 17.42 & 0.561 \\
F & Only national subsidy & Only CDTI loan & 0.006 & 11.35 & 0.991 \\
G & Only European subsidy & Only CDTI loan & 0.052 & 17.72 & 0.541 \\
H & Only subsidies & Only CDTI loan & 0.007 & 11.72 & 0.897 \\
I & CDTI loans \& subsidies & Only CDTI loan & 0.010 & 11.77 & 0.895 \\
J & Only European subsidy & Only national subsidy & 0.030 & 12.19 & 0.875 \\
K & CDTI loans \& subsidies & Only subsidies & 0.016 & 18.60 & 0.483 \\
\hline \hline
\end{tabular}

Notes: LR Chi2 reports the test on overall significance of the probit model after the matching. 
Table A.7: Balancing tests after matching. Large firms vs SMEs

\begin{tabular}{|c|c|c|c|c|c|c|c|c|c|}
\hline & \multirow[b]{2}{*}{ Case } & \multirow[b]{2}{*}{ Actual status } & \multirow[b]{2}{*}{ Counterfactual } & \multicolumn{3}{|c|}{ Number of observations } & \multirow[b]{2}{*}{ Ps R2 } & \multirow[b]{2}{*}{ LR Chi2(N) } & \multirow[b]{2}{*}{ p $>$ Chi2 } \\
\hline & & & & Total & $\begin{array}{c}\text { Treated } \\
\text { group }\end{array}$ & $\begin{array}{c}\text { Control } \\
\text { group }\end{array}$ & & & \\
\hline \multirow{11}{*}{ Large firms } & A & Only CDTI loan & No public funding & 356 & 185 & 171 & 0.011 & 6.31 & 0.991 \\
\hline & $\mathrm{B}$ & Only national subsidy & No public funding & 343 & 178 & 165 & 0.009 & 5.24 & 0.997 \\
\hline & $\mathrm{C}$ & Only European subsidy & No public funding & 87 & 44 & 43 & 0.033 & 4.42 & 0.999 \\
\hline & $\mathrm{D}$ & Only subsidies & No public funding & 456 & 230 & 226 & 0.014 & 14.37 & 0.641 \\
\hline & $\mathrm{E}$ & CDTI loans \& subsidies & No public funding & 248 & 127 & 121 & 0.014 & 6.20 & 0.992 \\
\hline & $\mathrm{F}$ & Only national subsidy & Only CDTI loan & 185 & 95 & 90 & 0.031 & 17.61 & 0.414 \\
\hline & $\mathrm{G}$ & Only European subsidy & Only CDTI loan & 53 & 26 & 27 & 0.186 & 19.04 & 0.326 \\
\hline & $\mathrm{H}$ & Only subsidies & Only CDTI loan & 217 & 109 & 108 & 0.020 & 10.66 & 0.874 \\
\hline & $\mathrm{I}$ & CDTI loans \& subsidies & Only CDTI loan & 161 & 80 & 81 & 0.047 & 19.88 & 0.281 \\
\hline & $\mathrm{J}$ & Only European subsidy & Only national subsidy & 63 & 32 & 31 & 0.189 & 24.60 & 0.104 \\
\hline & $\mathrm{K}$ & CDTI loans \& subsidies & Only subsidies & 222 & 117 & 105 & 0.021 & 9.40 & 0.927 \\
\hline \multirow{11}{*}{ SMEs } & $\mathrm{A}$ & Only CDTI loan & No public funding & 756 & 384 & 372 & 0.011 & 13.36 & 0.770 \\
\hline & $\mathrm{B}$ & Only national subsidy & No public funding & 1054 & 536 & 518 & 0.007 & 12.78 & 0.804 \\
\hline & $\mathrm{C}$ & Only European subsidy & No public funding & 173 & 89 & 84 & 0.056 & 14.78 & 0.677 \\
\hline & $\mathrm{D}$ & Only subsidies & No public funding & 1194 & 607 & 587 & 0.006 & 15.51 & 0.627 \\
\hline & $\mathrm{E}$ & CDTI loans \& subsidies & No public funding & 459 & 233 & 226 & 0.027 & 19.81 & 0.343 \\
\hline & $\mathrm{F}$ & Only national subsidy & Only CDTI loan & 439 & 221 & 218 & 0.018 & 21.44 & 0.258 \\
\hline & $\mathrm{G}$ & Only European subsidy & Only CDTI loan & 137 & 69 & 68 & 0.069 & 16.77 & 0.539 \\
\hline & $\mathrm{H}$ & Only subsidies & Only CDTI loan & 499 & 245 & 254 & 0.010 & 11.77 & 0.860 \\
\hline & $\mathrm{I}$ & CDTI loans \& subsidies & Only CDTI loan & 338 & 168 & 170 & 0.007 & 4.99 & 0.998 \\
\hline & $\mathrm{J}$ & Only European subsidy & Only national subsidy & 171 & 87 & 84 & 0.037 & 9.65 & 0.918 \\
\hline & $\mathrm{K}$ & CDTI loans \& subsidies & Only subsidies & 404 & 206 & 198 & 0.014 & 10.24 & 0.924 \\
\hline
\end{tabular}

Notes: LR Chi2(N) reports the test on overall significance of the Probit model after the matching (N is 17 for large firms and 18 for SMEs) 